
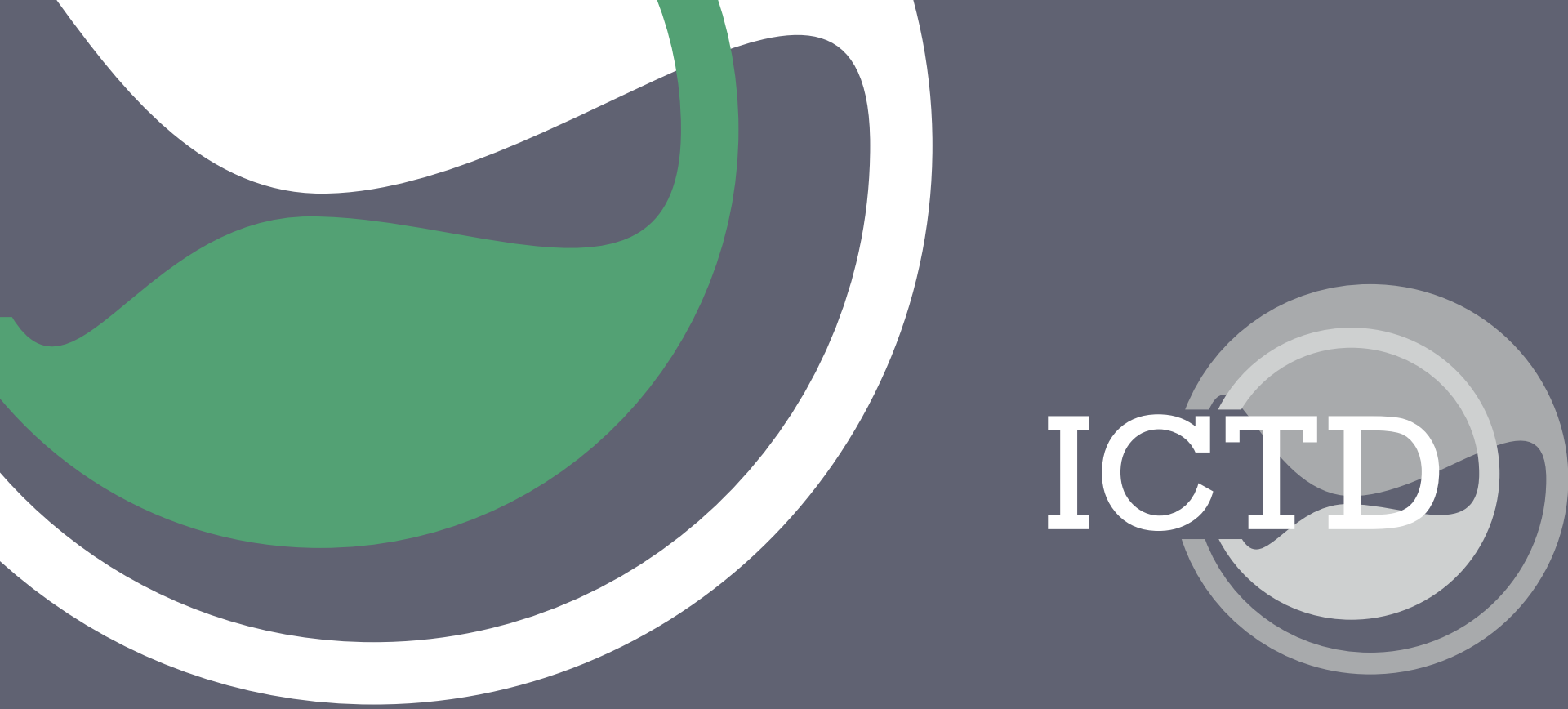

African Tax Administration Paper 24

How Clean Are Our Taxpayer Returns? Data Management in Uganda Revenue Authority

Jova Mayega, Ronald Waiswa, Jane Nabuyondo and Milly Nalukwago Isingoma

April 2021 


\section{African Tax Administration Paper 24}

\section{How Clean Are Our Taxpayer Returns? Data Management in Uganda Revenue Authority}

Jova Mayega, Ronald Waiswa, Jane Nabuyondo and Milly Nalukwago Isingoma

April 2021 
How Clean Are Our Taxpayer Returns? Data Management in Uganda Revenue Authority Jova Mayega, Ronald Waiswa, Jane Nabuyondo and Milly Nalukwago Isingoma

ICTD African Tax Administration Paper 24

First published by the Institute of Development Studies in April 2021

(C) Institute of Development Studies 2021

ISBN: [978-1-78118-797-5]

DOI: [10.19088/ICTD.2021.007]

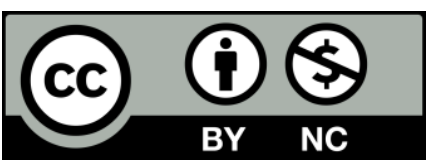

This is an Open Access paper distributed under the terms of the Creative Commons Attribution Non Commercial 4.0 International license, which permits downloading and sharing provided the original authors and source are credited - but the work is not used for commercial purposes. http://creativecommons.org/licenses/by-nc/4.0/legalcode

Available from:

The International Centre for Tax and Development at the Institute of Development Studies, Brighton BN1 9RE, UK

Tel: +44 (0) 1273606261

Email: info@ictd.ac

Web: www.ictd.ac/publication

Twitter: @ICTDTax

Facebook: www.facebook.com/ICTDtax

IDS is a charitable company limited by guarantee and registered in England

Charity Registration Number 306371

Charitable Company Number 877338 


\title{
How Clean Are Our Taxpayer Returns? Data Management in Uganda Revenue Authority
}

\author{
Jova Mayega, Ronald Waiswa, Jane Nabuyondo and Milly Nalukwago Isingoma
}

\section{Summary}

The paper assesses the cleanliness of taxpayer returns at the Uganda Revenue Authority (URA) in terms of: (a) completeness - the extent to which taxpayers submit all the required information as specified in the return forms; (b) accuracy - the extent to which the submitted information is correct; (c) consistency - the extent to which taxpayers submit similar information in cases where the same information is required in different types of tax returns, or submitted in the same type of tax return, but for different time periods; and (d) permanence - the extent to which the returns are likely to be later modified by taxpayers.

By digitising business processes, URA is collecting large amounts of data on individuals and firms in the course of administering taxation. This data is indeed a strategic asset as it can be used for improving tax compliance. The data however needs to be of sufficient quality for accurate decision making. Our assessment has identified a number of data quality gaps that exist in URA tax return information. Specifically, we found: (a) high proportions of incomplete returns and/or returns with inaccurate/wrong information, especially with regard to identification details such as taxpayer identification numbers (TINs), names and business locations; (b) a number of returns with inconsistent information; (c) a sizeable number of returns amended, with some returns amended several times. Lastly, we found that the data gaps have persisted over the years and cut across different taxpayer segments - large, medium, small and government entities.

The data gaps are a result of: (a) people-related causes; (b) complexity of the return forms; (c) gaps in the return forms; (d) weakness in the e-tax system and low levels of system integrations; and (d) weak tax return management processes.

To mitigate the data gaps, URA needs to: (1) upgrade the e-tax system such that different modules within e-tax are integrated to automatically verify some of the submitted information with that which is already available in the e-tax system; (2) integrate e-tax with other internal as well as external systems; (3) pre-populate some of the information in the tax return - this may involve designing online return forms similar to the one for presumptive taxpayers; (4) deliberately penalise taxpayers for wrong information submitted; and (5) continuously teach taxpayers how to file tax returns, and also the implications of submitting wrong information to URA.

Keywords: tax returns, completeness, accuracy, permanence, consistency, e-tax, automation.

Jova Mayega has 12 years of experience in research and data management. He has worked with URA since 2013 and is currently in charge of statistics and policy analysis. Jova also served as a statistician at the Uganda Bureau of Statistics between 2010 and 2013, and as a data manager at BRAC Uganda from 2008 to 2010.

Ronald Waiswa is a supervisor for Research and Policy Analysis at Uganda Revenue Authority's Research, Planning and Development Division. He also heads research and training at Lida Africa. He has collaborated with ICTD on a number of research projects in Uganda and Ethiopia on issues including taxing wealthy individuals, public sector agencies and improving tax compliance. He has also collaborated with the United Nations University 
World Institute for Development Research (UNU-WIDER) on research projects including tax compliance of presumptive taxpayers and tax benefit microsimulation modelling.

Jane Nabuyondo is a supervisor for Business Intelligence with 12 years' experience in tax administration and vast knowledge of government (public) operations. She is also the team lead in development and maintenance of the URA Data Warehouse/Business Intelligence solution including overseeing the implementation of data governance initiatives in URA that will support the organisation to become a data driven entity.

Milly Nalukwago Isingoma is the Assistant Commissioner for Research, Planning and Development at URA. She is also the URA Head of Delegation to the East African Revenue Authorities Technical Committee and a member of ICTD's Centre Advisory Group. 


\section{Acknowledgements}

We are grateful to the International Centre for Tax and Development (ICTD) for the financial support and to ICTD colleagues for the invaluable comments on the earlier drafts of this paper. We express our sincere appreciation to the different individuals that we approached during the interviews at the Uganda Revenue Authority (URA) and to the taxpayers that responded to our survey.

The contents of this document are the sole responsibility of the authors and can under no circumstances be regarded as reflecting the position of URA or ICTD.

\section{Acronyms}

$\begin{array}{ll}\text { ASYCUDA World } & \text { Automated system for customs data } \\ \text { COO } & \text { Central Operations Office } \\ \text { GPBT } & \text { Gaming and Pool Betting Tax } \\ \text { E-filing } & \text { Electronic filing } \\ \text { E-hub } & \text { Localised name for URA data warehouse } \\ \text { E-tax } & \text { Domestic taxpayer management system used by URA } \\ \text { ICTD } & \text { International Centre for Tax and Development } \\ \text { IMF } & \text { International Monetary Fund } \\ \text { IT } & \text { Information technology } \\ \text { ITA } & \text { Income Tax Act } \\ \text { LTO } & \text { Large Taxpayers' Office } \\ \text { MTO } & \text { Medium Taxpayers' Office } \\ \text { PAYE } & \text { Pay as you earn } \\ \text { PSO } & \text { Public Sector Office } \\ \text { STO } & \text { Small Taxpayers' Office } \\ \text { TADAT } & \text { Tax Administration Diagnostic Assessment Tool } \\ \text { TIN } & \text { Taxpayer identification number } \\ \text { URA } & \text { Uganda Revenue Authority } \\ \text { VAT } & \text { Value added tax } \\ \text { WHT } & \text { Withholding tax }\end{array}$




\section{Contents}

Summary 3

Acknowledgements

Acronyms $\quad 5$

$\begin{array}{lr}\text { Introduction } & \mathbf{8}\end{array}$

1 The research 9

$2 \quad$ Tax return filing in URA 11

$3 \quad$ Return process: pre and post e-tax period 13

$4 \quad$ Cleanliness of taxpayers' returns data $\quad 15$

4.1 Completeness and accuracy of tax returns 16

4.1.1 Rental income tax returns $\quad 16$

4.1.2 Withholding tax return $\quad 18$

4.1.3 Value added tax return 19

4.1.4 PAYE tax return gaps 21

4.1.5 Income tax return gaps 22

4.2 Consistency of information submitted in tax returns 23

4.3 Permanence of tax return information 26

4.4 What explains the high rates of tax return amendments, especially
for income tax?

$5 \quad$ Causes of the data gaps in taxpayer returns 28

5.1 People-related causes $\quad 28$

5.2 Complexity of return forms 31

5.3 Gaps in the tax return forms 32

5.4 Weaknesses in the e-tax system and low level of systems integration 32

5.5 Weak return management processes 32

$6 \quad$ Conclusion and way forward 32

$\begin{array}{ll}\text { References } & 34\end{array}$

Tables

Table 1

Table 2

Table 3

Table 4

Table 5

Table 6

Table 7

Table 8

Table 9

Table 10

Table 11

Table 12

Different types of tax returns filed at URA

12

Cleanliness of information on location of buildings in rental returns 18

Cleanliness of suppliers' information in WHT returns 18

Proportion of untraceable suppliers by size of withholding tax agent $\quad 19$

VAT sales to registered and unregistered clients 20

Quality of employee TINs in the PAYE return 21

Wrong employee TINs in December PAYE returns 2014/15-2019/20 21

Quality of company directors' TINs in income tax returns 22

Inconsistency between closing stock and inventory in the same return 23

Consistency of opening stock and closing stock in income tax returns 24

Consistency of carried forward losses in income tax returns 24

Consistency of VAT offsets carried forward in January returns

from December returns

25

Table $13 \quad$ Importers not registered for income tax FY 2018/19 26

Table $14 \quad$ Proportion of amended income tax returns 26 
Table 15

Table 16

Table 17

Table 18

Table 19

\section{Figures}

Figure 1

Figure 2

Figure 3

Figure 4

Figure 5
Proportion of amended VAT, PAYE and withholding tax returns

Taxpayer opinions on the causes of errors in tax returns

29

Timeliness of income tax return filing

29

Timeliness of monthly VAT, PAYE and WHT return filing

30

Ease of filing different tax returns

Post e-tax return filing journey

15

Cleanliness of identification details in rental tax returns for tenants and landlords

Cleanliness of tenants' TINs declared by landlord's size

17

Gross amount of supplies made by traceable and

untraceable suppliers

19

Proportion of invalid employee TINs by employer size

22 


\section{Introduction}

By digitising business processes, tax and customs authorities in Africa are collecting large amounts of data on individuals and firms in the course of administering taxation. This data is indeed a strategic asset to tax administrations as it can be used for improving tax compliance through detecting and controlling misreporting by taxpayers. It can also be used for generating policy-relevant research that will be useful to policymakers and researchers alike. For effective decision making and successful management of tax administrations, the data needs to be of sufficient quality. Low quality data obviously represents a compliance risk but can also lead to bad decisions (Nathan Associates Inc 2018; IMF 2015a).

This paper assess the cleanliness of taxpayer returns at the Uganda Revenue Authority (URA) in terms of (a) completeness - the extent to which taxpayers submit all the required information as specified in the return forms; (b) accuracy - the extent to which the submitted information is correct; (c) consistency - the extent to which taxpayers submit similar information in cases where the same information is required in different types of tax return, or submitted in the same type of tax return, but for different time periods. For instance, in the case of the income tax return, whether the closing stock at the end of the year is similar to the declared opening stock at the start of a new year of income; and (d) permanence - the extent to which returns are likely to be later modified by the taxpayer.

This research is the second phase of a larger research project on data management at URA. The first phase of the project assessed the quality of data in the taxpayer register database where a number of data quality gaps were identified such as a large number of taxpayers sharing key contact information such as contact numbers and emails; among others, taxpayers owning multiple taxpayer identification numbers (TINs). For instance, 16,017 individual taxpayers had recorded the same national identification number; 6,173 had the same passport number; 3,360 shared a single email address, and 1,742 had given the same phone number (Mayega, Ssunna, Mubajje, Nalukwago and Muwonge 2019).

In the past two decades, African tax administrations have embraced automation of their tax systems to a higher degree. The introduction of improved IT systems has been hailed for its role in making it easy for taxpayers to comply, improving tax compliance, reducing opportunities and incentives for collusion and corruption by tax officials and increasing the administrative efficiency of tax administrations (OECD 2006; OECD 2007; Mayega et al. 2019). In assessing the performance of tax administrations, the International Monetary Fund (IMF), in its Tax Administration Diagnostic Assessment Tool (TADAT), considers the use of automated tax systems as a key performance indicator. Specifically, the IMF assesses tax administrations on the extent to which tax returns are filed electronically and the use of electronic payment methods. Countries like Uganda and Kenya for instance scored an 'A' on these two performance indicators.

The two most common aspects of digitising tax services are the electronic filing and payment of taxes. In Uganda and Kenya, it is mandatory to file tax returns and make payments for all tax heads using electronic systems. In Rwanda, by 2015, all value added tax (VAT) and pay as you earn (PAYE) returns were filed electronically but only large and medium taxpayers were filing income tax returns (corporate income tax - CIT - and personal income tax - PIT) electronically. In Zambia, by 2016, at least 70 per cent of the returns of core tax heads were made through the online system. In Tanzania all payments were made electronically but efilling was not mandatory and therefore taxpayers were free to alternate between e-filing and manual filing (IMF 2019; IMF 2016a, b and c; IMF 2015b).

In Uganda's case, the Uganda Revenue Authority (URA) automated almost all its processes for the management of domestic taxes, customs and administration operations. Domestic tax processes including registration of taxpayers, filing tax returns, payment of taxes, tax refund 
claims, and objections are automated in the e-tax system. Customs processes such as import and export declarations and valuations are automated in the Automated System for Customs Data (ASYCUDA World) while administrative processes such as human resource management, finance, and procurement are managed in the Enterprise Resource Planning (ERP) system (Mayega et. al. 2019).

However, despite the heavy investment in electronic systems, the high expectations from these IT investments have often been disappointed, reflecting excessive focus on the tool rather than the aim. More specifically, the integrity of the data contained in these IT systems appears to be a main issue of concern. The IMF reports that decision makers in revenue agencies are frequently complaining of the lack of good managerial information for timely decisions and inconsistent data for appraising the performance of core operations (IMF 2015a). Similarly, the different country TADAT assessments carried out by the IMF have all concluded that data on the countries' taxpayer registers specifically is inaccurate and that the staff of revenue agencies have low confidence in the data.

So far, apart from IMF reports telling us that there is a problem with the quality of the data in revenue authorities, the extent of the problem, the specific issues and the causes of the errors are not known. Similarly, assessments have focused on the quality of the data on the taxpayer registers. Evidence on the cleanliness of the taxpayer returns, customs declarations, and tax refunds databases, among others, is still lacking.

\section{The research}

Against this background, this research analyses the cleanliness of tax return records at URA. It highlights the issues that data users including URA staff, researchers, and analysts among others need to be aware of and/or carry out on tax returns before using the data for its intended purpose. Filing of tax returns is the second obligation of taxpayers after they are registered. It is important to ensure that revenue agencies are receiving correct and accurate tax return information for three main reasons. First, it is the basis for enforcing compliance on taxpayers who file returns but do not pay or those who grossly under declare. Second, it is the basis for forecasting the amount of revenue expected to be collected for the next period. Third, tax return data can be used to expand the taxpayer register. For instance, in the withholding tax return, ${ }^{1}$ filers are required to disclose details of those suppliers that they withheld from. Similarly, expenses such as purchases declared in the income tax return are required to be backed up with details of suppliers. Some of these suppliers are not registered and therefore can be identified from submitted tax returns.

The paper addresses three research questions.

i. What data gaps exist in URA tax return records and what additional work do data users (staff, researchers etc.) have to carry out on tax returns before they can use them for their intended purpose, such as calculating tax liabilities and conducting research?

ii. What are the causes of the errors in tax return records?

iii. To what extent can the data gaps be eliminated by making improvements to URA procedures?

Withholding tax is a form of income tax deducted at source and remitted to URA in advance by the payer. The person making payment is obliged to withhold tax and is referred to as a withholding agent and the person receiving payments from which tax is required to be withheld is the payee. 
To answer these questions, we employed four main approaches: analysis of tax return forms and administrative records on tax returns, a review of the tax return process, interviews with key officials at URA and a taxpayer survey.

\section{a) Analysis of return forms and administrative tax records}

We examined the different tax return forms to ascertain the available data quality checks and verification controls. We also extracted data on different variables (fields) in the tax return forms for the different tax heads to check for possibilities of inaccurate records. Our interest was to check if the forms are able to validate the submitted data in the returns as well as to verify if the system is able to validate submitted return information with other existing data in URA's systems, such as the taxpayer register and return data for other taxpayers. If, for instance, taxpayer $\mathrm{X}$ declares taxpayer $\mathrm{Y}$ as his/her supplier, is the system able to check whether the values declared by both taxpayers in their respective returns are consistent? Or if a taxpayer declares an individual as a director, landlord or tenant etc., are the details such as name and tax identification number declared validated with the information in the taxpayer register?

\section{b) Review of tax return processes}

We reviewed the different stages of filing tax returns right from the point when the taxpayers download the return forms on the URA website up to the point when the return is accepted by URA as a final return. Our interest was to determine how effective the different stages were in ensuring that quality tax returns are submitted. We looked at how the submitted returns are managed in the e-tax system and the levels of verification required for a submitted tax return to be accepted by URA.

\section{c) Interviews with URA staff}

At URA, we engaged in discussions with staff in the domestic taxes department. Specifically, we targeted staff in the business process management division, central operations office (COO), and revenue assurance (RA) functions, and compliance officers in different offices, as well as senior staff that were in URA before the digitisation of tax administration operations. Staff in the business process management division are mandated to manage the e-tax system. They are responsible for making changes to the e-tax system and ensuring that it is working efficiently. Staff in the $\mathrm{COO}$ and RA units are mandated to carry out analysis of previous and current returns to identify risky taxpayers in the central region. Compliance officers in the different tax offices countrywide perform return analysis for taxpayers in upcountry stations.

Lastly, senior officials were engaged specifically to assess the history of return filing in URA, especially before e-tax was implemented. These discussions with URA staff were useful for us to appreciate the return process, the possible causes of errors and the measures that URA should take to mitigate the gaps.

\section{d) Taxpayer survey and interviews}

To better understand the challenges that taxpayers have with the tax return as well as some of the causes of the data gaps, we sent out an online questionnaire to 18,361 taxpayers using SurveyMonkey. The taxpayers were selected from among small, medium and large taxpayers from different districts across the country. We also conducted phone interviews with 100 taxpayers whose return records had significant errors. A total of 865 taxpayers completed the online survey. 


\section{Tax return filing in URA}

A tax return is a legal document which must be dated and signed by the taxpayer or the taxpayer's appointed agent and includes a declaration that the return is complete and accurate. ${ }^{2}$ Tax return filing is a periodic activity carried out by every eligible taxpayer (individuals, companies, trusts, government organisations or partnerships) using prescribed Excel forms which are downloadable from the URA website. A taxpayer fills the forms and submits them back to URA's e-tax system. Presumptive taxpayers file a simplified return online. Before July 2015 , they filed normal income tax returns and had to use downloadable forms like other income taxpayers. In July 2015, the new simplified e-filing system was introduced for presumptive taxpayers. The new e-filing system does not require filling Excel forms; instead, taxpayers can directly file their tax returns using an online form on URA's etax web page. Presumptive taxpayers only need to specify their taxpayer identification number, estimated annual turnover and business location and then the system automatically calculates their applicable tax payable. The system also automatically generates a tax payment registration slip which these taxpayers use to pay the applicable income taxes to the bank at that same time (see Jouste, Nalukwago and Waiswa 2021 for the e-filing system).

There are different types of tax returns for the different domestic tax heads administered by URA. There are no tax returns for the non-tax revenues. The different tax returns are summarised in Table 1 below. 


\section{Table 1 Different types of tax returns filed at URA}

\begin{tabular}{|c|c|c|}
\hline No & Return type & Return description \\
\hline 1 & $\begin{array}{l}\text { Income tax return } \\
\text { For individuals, and non- } \\
\text { individuals }{ }^{4}\end{array}$ & $\begin{array}{l}\text { - A return of income is a declaration by the taxpayer of the income earned or loss } \\
\text { made during the year. The return captures information on income, expenses, } \\
\text { assets, liabilities, chargeable income, tax payable etc. } \\
\text { Taxpayers first file a provisional income tax return by the sixth month of the year of } \\
\text { income indicating the estimated gross turnover or chargeable income. }{ }^{5} \\
\text { - The final return is filed not later than six months after the end of the year of income. }{ }^{6}\end{array}$ \\
\hline 2 & $\begin{array}{l}\text { Presumptive tax return } \\
\text { For small taxpayers with } \\
\text { annual turnover between } \\
\text { UGX10 million (USD2,688) } \\
\text { and UGX150 million } \\
\text { (USD40,318) }\end{array}$ & $\begin{array}{l}\text { - Taxpayers with multiple businesses file all their information in the same return. } \\
\text { - A taxpayer can apply to URA to be taxed under the normal income tax regime if they } \\
\text { demonstrate that they are able to maintain proper records. In this case they file the } \\
\text { normal income tax return. } \\
\text { - A final tax. No deductions for expenses and no tax credits are allowed. }\end{array}$ \\
\hline 3 & $\begin{array}{l}\text { Rental income tax return } \\
\text { For individuals and non- } \\
\text { individuals }\end{array}$ & $\begin{array}{l}\text { - An annual return that must be filed not later than six months after the end of the year } \\
\text { of income. Captures information on landlords' and tenants' identification details, } \\
\text { location of property, gross rental income, rental expenses, rental tax payable etc. }\end{array}$ \\
\hline 4 & $\begin{array}{l}\text { Withholding tax (WHT) } \\
\text { return }{ }^{11} \\
\text { For withholding agents - } \\
\text { individuals and non-individuals }\end{array}$ & $\begin{array}{l}\text { - WHT is deducted at source and remitted to URA in advance by the payer. } \\
\text { - WHT returns are monthly returns supposed to be filed within } 15 \text { days after the end } \\
\text { of the month in which the WHT agent made the payment. } \\
\text { WHT returns in respect of a performance by non-resident entertainers or sports } \\
\text { persons are due within five days of the performance. } \\
\text { The return specifies identification details of both the WHT agent and the payee, } \\
\text { amounts paid and the applicable tax withheld. }\end{array}$ \\
\hline 5 & $\begin{array}{l}\text { Pay as you earn (PAYE) } \\
\text { return } \\
\text { For employers }\end{array}$ & $\begin{array}{l}\text { - The PAYE return is a monthly return filed by every employer, usually non-individuals } \\
\text { such as companies, government and private organisations. } \\
\text { Employers file the PAYE return by the } 15^{\text {th }} \text { day of the subsequent month. The return } \\
\text { specifies the details of all employees such as the employee TIN, name, salary, } \\
\text { allowances, tax charged etc. }\end{array}$ \\
\hline 6 & $\begin{array}{l}\text { Value added tax (VAT) } \\
\text { return }\end{array}$ & $\begin{array}{l}\text { - The VAT return is a monthly declaration filed within } 15 \text { days after the end of the tax } \\
\text { period. } \\
\text { A VAT return must be filed whether there have been transactions in a given month } \\
\text { or not. } \\
\text { - Captures information on the input and output VAT, VAT payable, the amount of } \\
\text { input tax credit refund claimed, details of the taxpayer etc. }\end{array}$ \\
\hline 7 & $\begin{array}{l}\text { Local excise duty (LED) } \\
\text { return }\end{array}$ & $\begin{array}{l}\text { - The return for excisable goods is submitted by the } 21 \text { st day of the month following } \\
\text { the month in which delivery was made, while the return for services is due by the } \\
\text { 15th day of the month following the month in which payment for the services was } \\
\text { made. }\end{array}$ \\
\hline 8 & $\begin{array}{l}\text { Gaming and pool betting tax } \\
\text { (GPBT) return }\end{array}$ & $\begin{array}{l}\text { - The GPBT returns are filed weekly and monthly. } \\
\text { GPBT taxpayers are required to file the return every Wednesday of the week } \\
\text { following the week of transaction. All days in the week are supposed to be } \\
\text { accounted for irrespective of whether there were transactions or not. The taxpayer } \\
\text { after filing the return should make the necessary payment that relates to that } \\
\text { particular return in time. } \\
\text { Taxpayers are also required to lodge a tax return on a prescribed form by the } 15 \text { th } \\
\text { day of the following month. }{ }^{12}\end{array}$ \\
\hline
\end{tabular}

Source: Authors' own.

3 Sec. $92 \mathrm{~A}$ of the ITA

$4 \quad$ Those who qualify under Sec. 93 (a), Sec 93 (b)(i), Sec 93(b)(ii), Sec. 4(4), Sec. 87(1)(c) of the ITA are not required to file.

5 Sec. 112(4) for filing a provisional return and also Sec. 111(2) and (4) for due dates of provisional tax.

6 Sec. 92 of ITA.

7 Sec. $4(5)$ of ITA

$8 \quad$ Uganda Shilling to US Dollar average annual exchange rates used in this paper are: FY 2015/2016: UGX3436 to US\$1 2016/17: UGX3526 to US $\$ 1$; 2017/18: UGX 3651 to US $\$ 1 ; 2018 / 19$ : UGX3750 to US $\$ 1 ; 2019 / 20$ : UGX3729 to US $\$ 1$.

9 Professionals are not treated as presumptive taxpayers, even in cases where they earn less that UGX150 million.

10 Part XII, Sec 114(1), (2), (3) of the ITA.

11 WHT provisions are under part XIII of the ITA entitled 'Withholding of tax at the source'.

12 Sec. 50 of the Lotteries and Gaming Act. 


\section{Return process: pre and post e-tax period}

Before the introduction of electronic filing in November 2009, return filing was largely a manual process. The only point of automation was at the point of data entry of the submitted returns where the information was captured in different in-house systems. There were three separate systems at that time: the Payesys for capturing PAYE returns, VATPlus for VAT returns and the self-assessor system for income tax returns.

To file a tax return, a taxpayer had to physically visit a URA office and specifically his/her jurisdictional office where he/she was registered. If for instance a taxpayer stayed or operated in an upcountry district but his/her tax matters were handled by a tax office in Kampala, as was often the case for large taxpayers, they had to travel to Kampala to file a return. For PAYE and VAT returns, URA had developed serialised tax return booklets which taxpayers could pick up from a URA office. The booklets had leaflets that taxpayers could fill in triplicate and the leaflets were accompanied by a payment advice form. The filled forms would then be taken to the bank and payment of taxes done. At that time, filing and payment of taxes were done at the same time. In other words, taxpayers could file returns only if they had the money to pay in taxes. At the end of every day, the bank would then summarise all the returns and send a till sheet accompanied by a copy of the return forms to URA. The return copies submitted to URA could then be taken to the data centre in Kampala to capture the data in the respective systems. Copies of the returns were then added to the taxpayers' files in the registry division.

Similarly, income taxpayers were also required to pick up a manifold (income tax return booklet) from URA which they could fill at the end of the year and submit to URA together with their books of accounts. These were submitted to URA officers to examine the accounts and then issue tax assessments before they could be sent to the data centre to capture the data in the self-assessor system.

According to the interviewed senior tax officials that were in URA before e-tax, the manual system had a number of challenges including: (1) a backlog of taxpayers' returns not captured in the systems due to low levels of staffing in the data centre; (2) upcountry tax offices had to wait for their tax returns to accumulate before they could send them to Kampala to be captured in the systems; (3) as a result of low staff capacity, the data in the system was never updated, even if the taxpayers' records were amended; (4) allegedly, fraudulent practices were common such as taxpayers conniving with bank officers and URA staff to back date the filing data in case of delays in filing; (5) tax returns could easily get misplaced; (6) It was very difficult to determine who filed and who didn't file returns; and lastly (7) the process was very costly to taxpayers. For instance: (a) some taxpayers had to travel long distances to their jurisdictional tax office to file a return; (b) the filing dates were characterised by long queues; and (c) since filing and paying of taxes were supposed to be done at the same time, some taxpayers incurred penalty charges for late filing when they were unable to pay at that time (interviews with senior tax officials).

Electronic filing was piloted in November 2009 with taxpayers in Kampala East tax office and then expanded to the Medium Taxpayers' Office (MTO) and the Large Taxpayers' Office (LTO) in January 2010. By the end of 2010, about 90 per cent of all tax returns were filed online and by the end of 2011, all returns were filed online on the URA web portal through taxpayers' accounts obtained at the point of registering for a TIN. However, until March 2011, when the Electronic Signature Act and Electronic Transactions Act were passed into law, taxpayers were still required to print their submitted tax returns, sign them and submit them physically to a URA office. For each tax return, the e-tax system created a task for a URA officer to scan the signed page and upload it in the system. 
URA designed Excel templates (return forms) for the different tax types. These are downloadable from the URA web portal. To ensure data quality, the Excel forms were developed with macros to validate the completeness and arithmetical accuracy of the information submitted. The validated form is then submitted to the URA web portal which also performs further validation checks such as whether the TIN of the taxpayer exists in the registration database, whether the specified suppliers are registered for VAT, and for arithmetical accuracy, among others. The validation checks were however very limited in the early years of piloting the system and they remain limited even now. At the start of electronic filing, validation checks were relaxed because URA wanted to get taxpayers on board and therefore limited the restrictions or validation checks which would prevent a return being accepted by the system. More restrictions have been implemented along the way but a number of checks are still not implemented because of the fear by URA management that some taxpayers will end up not filing tax returns, or file returns with missing information. For instance, while the Income Tax Act requires that taxpayers that declare suppliers who supply them with supplies of at least UGX1 million must include suppliers' TINs, URA is yet to implement this requirement.

Originally, to ensure the completeness and accuracy of return information, the submitted returns were subjected to two more processes before they could be approved: the return verification and return approval processes. Before 2014, all returns had to be reviewed by one or two officers before they could be approved. Tax returns that passed the system validation checks could be sent to the approval authority for an officer to decide whether to accept or reject them, while returns that failed the system validation checks were sent to the verification authority where URA officers were required to review the information before the returns were sent to the approval authority for a final decision.

In 2014, the verification process was removed and all returns that passed the system validation checks were automatically approved while those that failed were sent to the approval authority where a URA officer could vet them and decide whether to approve or reject them. The removal of the verification process was because of the heavy workload of verifying and approving returns. Even with the removal of verification tasks, the workload still remained heavy and there were general concerns that taxpayers' returns were not being approved on time and that URA officers were just approving returns without thorough scrutiny. Accordingly, in October 2019, the management of the domestic tax department decided that all returns should be automatically approved and a separate team of officers be set up to examine and perform risk analysis on the submitted returns. The output of this team formed the domestic tax department's audit plan and compliance improvement plan for the year.

The return process and the changes over the years are depicted in Figure 1 below. 
Figure 1 Post e-tax return filing journey

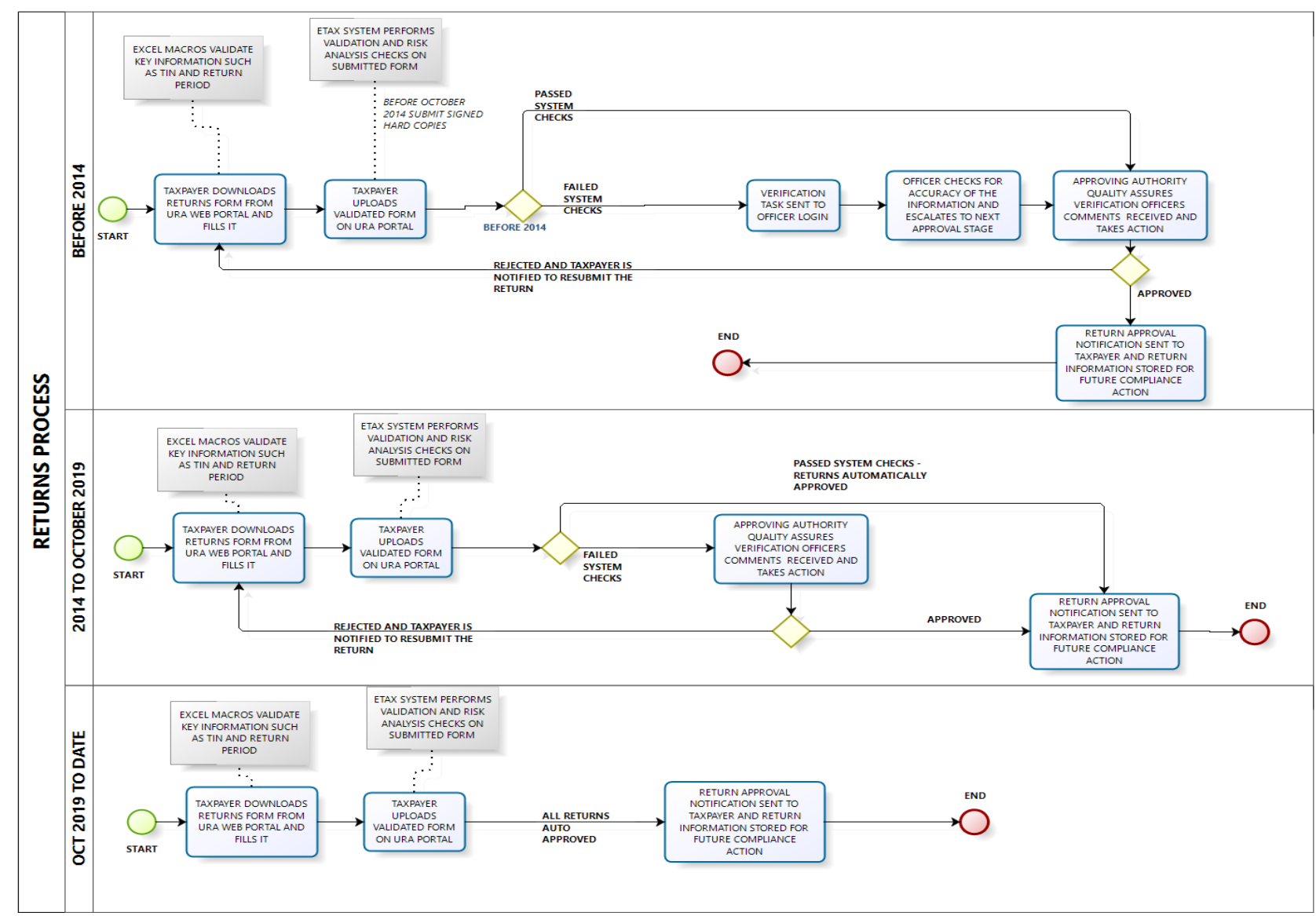

Source: Authors' own.

\section{Cleanliness of taxpayers' returns data}

While the introduction of electronic filing has played a great role in mitigating the challenges of the manual system and improving general tax administration efficiency, the system still suffers from a number of inaccuracies. The taxpayer registry has various data gaps (see Mayega et. al. 2019). In this assessment of tax returns, we have also identified a number of data gaps.

Specifically, we found that:

a) High proportions of taxpayers submit incomplete returns and/or returns with inaccurate/wrong information. Specifically, information that is especially useful for URA to identify new potential taxpayers and non-compliant taxpayers declared in returns is grossly unclean. For instance, in the rental income tax returns, tenants are required to declare their landlord's identification details, and vice versa. In the income tax returns, filers are required to declare company directors. Similarly, employers are required to declare their employees' identification details in the PAYE return, while withholding agents are required to declare details about their suppliers in the withholding returns. The identification information declared about these individuals is largely either missing or incorrect. As a result, URA misses the opportunity to identify and register potential taxpayers as well as to enforce compliance on the non-compliant taxpayers declared in the different tax returns. 
b) A number of taxpayers file inconsistent information especially when they are required to submit similar information in different returns/systems, or in the same type of return submitted at different time periods, or even in the same return but in different places in the form.

c) A sizeable number of returns are amended and some taxpayers amend the same return several times.

d) The data gaps have persisted over the years. In some cases, there have been slight reductions in the proportion of returns with data gaps and in other cases, the gaps have actually increased.

e) Lastly, the problems of unclean tax returns cut across all taxpayer segments - large, medium, small and government entities.

We discuss the extent of the data gaps for the different types of tax returns below.

\subsection{Completeness and accuracy of tax returns}

There is evidence of incomplete and wrong information submitted in the different returns as discussed below.

\subsubsection{Rental income tax returns}

The rental tax return completed by the landlord collects information on the tenant/s' TIN and name/s, the location of the premises, the period of tenancy and the gross rental income received/receivable. Tenants, on the other hand, declare their landlords when claiming for rental expenses in their income tax return, where they are also required to indicate the landlord's TIN and name, the location of the premises, the period of tenancy and the gross rent paid/payable. In both the landlord's rental tax return form and the tenant's income tax return, none of the fields are mandatory and none of the information submitted is validated by e-tax. In the end, the majority of the landlords, tenants and premise locations cannot be identified and traced.

\section{Specifically, we found that}

- The majority of landlords either do not declare their tenant/s' details or declare incorrect identification details such as TINs and names. Between 2014/15 and 2018/19, 85 per cent of the tenant/s' TINs declared by landlords were either missing or incorrect. On the other hand, tenants' declarations of their landlord's identification details appear cleaner. We found that the majority (67 per cent) of the landlords' TINs declared in tenants' returns were accurate and only 33 per cent of the returns had a missing or incorrect landlord TIN. Similarly, over the years, the proportion of incorrect/missing landlord TINs is decreasing, though marginally, as seen in Figure 2 . There are also many cases of incorrect names of landlords and tenants declared in tenants' and landlords' returns respectively. For instance, some of the names declared by tenants as their landlords include '0000', 'old park', 'missing', etc. Landlords also have a tendency to lump together their tenants and report them as 'various'. A total of 3,636 landlords declared their tenants' names as 'various'. The data submitted by tenants was cleaner than that declared by landlords. This is attributed to the fact that tenants have to include the rental expenses in their income tax return, but these expenses are only allowed as a deduction for income tax purposes if the landlord's identification details are correct. In contrast, landlords have no incentive to declare correct details about their tenants. In any fact, by hiding their tenants, landlords have the opportunity to even hide from URA some rental income earned. 
Quality of tenants' TINs declared by landlords

$100 \%$
$90 \%$
$80 \%$
$70 \%$
$60 \%$
$50 \%$
$40 \%$
$30 \%$
$20 \%$
$10 \%$
$0 \%$

$2014 / 15$

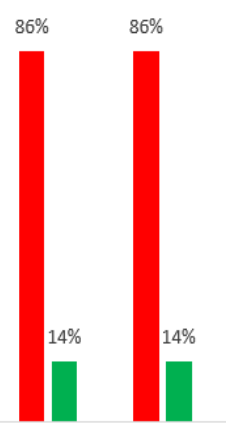

$2015 / 16$

$2016 / 17$

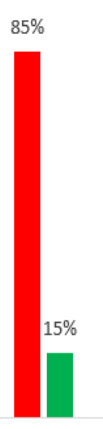

$2017 / 18$
Quality of landlords' TINs declared by tenants

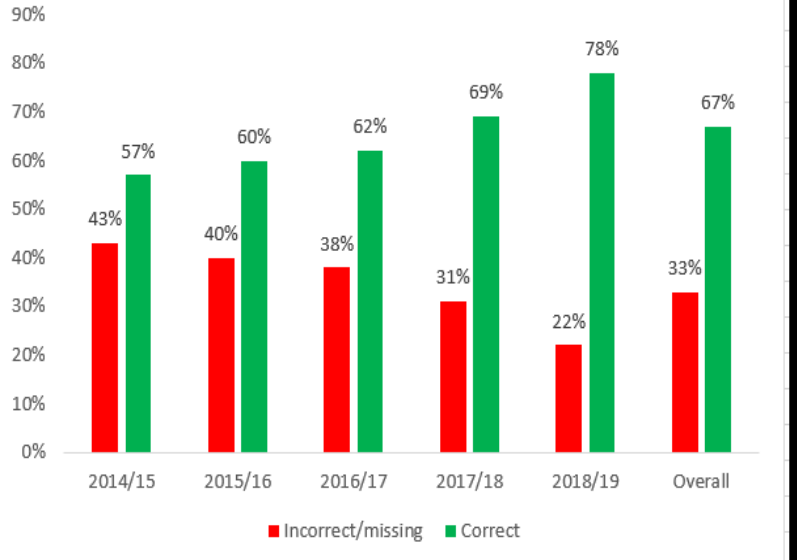

Source: Authors' own calculations from URA databases.

- Unclean records with regard to tenants' identification details provided by landlords are identified in all taxpayer (landlords) segments. For instance, while a higher proportion (88 per cent) of incorrect tenant/s' TINs were submitted by landlords in the Small Taxpayers' Office (STO), the proportion of invalid tenant TINs declared by landlords in the LTO and the MTO as well as the Public Sector Office (PSO) are also alarmingly high as seen in Figure 3.

\section{Figure 3 Cleanliness of tenants' TINs declared by landlord's size}

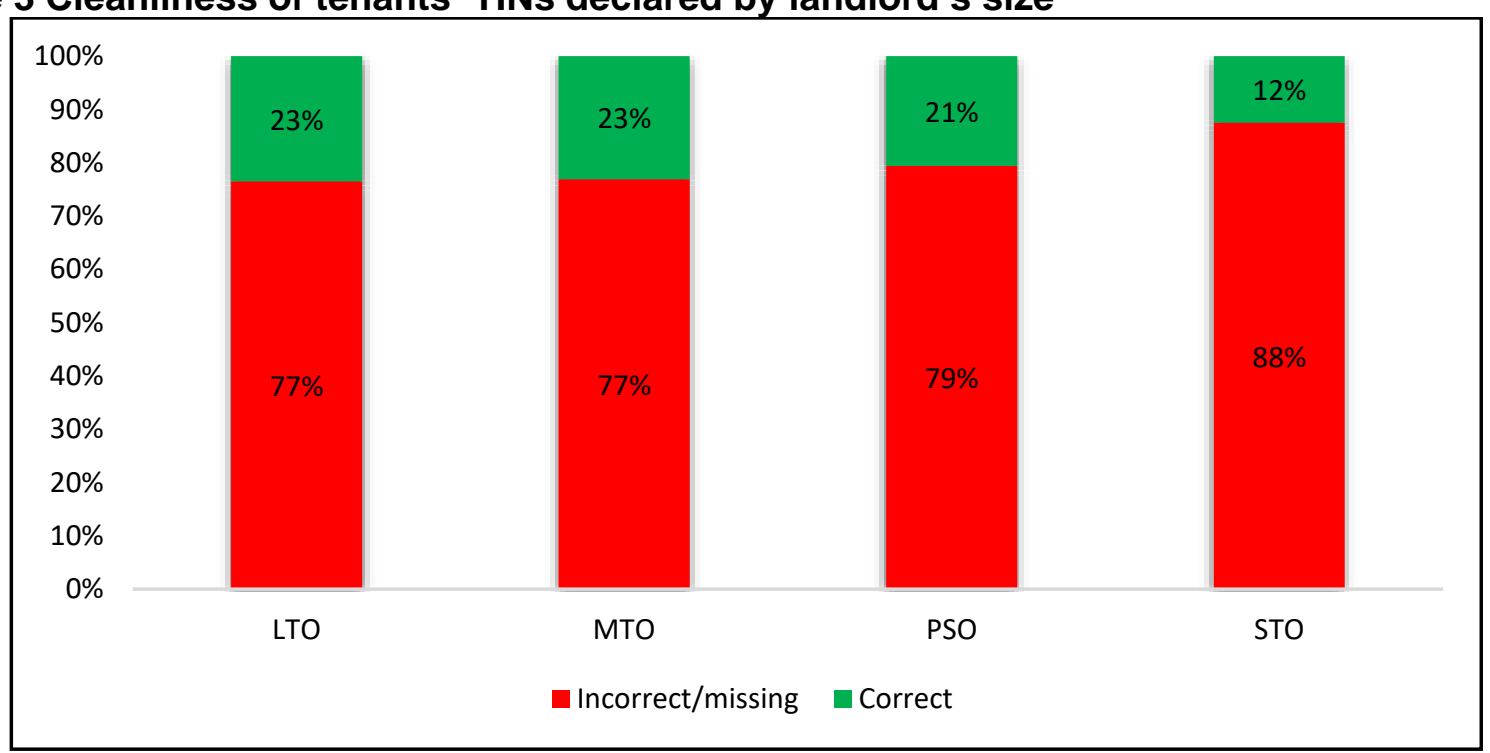

Source: Authors' own calculations from URA databases.

- The location of the buildings as declared by their owners (landlords) is also often wrong and/or incomplete. Over 77 per cent of the buildings declared in rental returns are either difficult or impossible to locate. For instance, some landlords declare building locations such as 'shop', plot 2, 000 etc. Others indicate the name of the district as the building location. For example, in 7,886 rental returns the location of the buildings was declared as Kampala and another 1,911 returns indicated Mbarara. The unclean data on building 
locations is in part due to the fact that Uganda, like many other developing countries, lacks an effective address system. By the end of 2019/20, only 22 per cent of the land was titled, where plot numbers where buildings are located can easily be established (MoFPED 2020). Even where the land is titled, such as in Kampala and Wakiso districts, most of the streets and buildings are not labelled and/or numbered as they are in other developed countries. In the end, building owners are often not in a position to declare valid or easy to identify locations for their buildings.

\begin{tabular}{lcccccc}
\multicolumn{6}{l}{ Table 2 } & Cleanliness of information on location of buildings in rental returns \\
\hline Location & $\mathbf{2 0 1 4 / 1 5}$ & $\mathbf{2 0 1 5 / 1 6}$ & $\mathbf{2 0 1 6 / 1 7}$ & $\mathbf{2 0 1 7 / 1 8}$ & $\mathbf{2 0 1 8 / 1 9}$ & Total \\
\hline Invalid & $70 \%$ & $75 \%$ & $79 \%$ & $78 \%$ & $79 \%$ & $77 \%$ \\
\hline Valid & $30 \%$ & $25 \%$ & $21 \%$ & $22 \%$ & $21 \%$ & $23 \%$ \\
\hline Total & $100 \%$ & $100 \%$ & $100 \%$ & $100 \%$ & $100 \%$ & $100 \%$ \\
\hline
\end{tabular}

Source: Authors' own calculations from URA databases.

\subsubsection{Withholding tax return}

Withholding tax returns collect information on the withholding agent's TIN, the return period, details of suppliers (i.e., persons from whom the withholding tax is recovered) such as the supplier TIN and name, details on the nature and date of payment, gross amounts paid, applicable tax rates and the amount of withholding tax withheld.

The WHT return also suffers from the same weaknesses as the rental return forms. Other than the TIN of the withholding agent and the return period, which are mandatory and validated by e-tax when the completed form is uploaded in the system, all the other variables are not mandatory and are not validated by e-tax upon uploading the form. As a result, there are a huge number of suppliers declared in the URA system who cannot be traced yet some of these suppliers are high income earners supplying goods and services worth billions of Uganda Shillings. Specifically, we found that

- Almost half (49 per cent) of the suppliers in WHT returns are hard to trace as their TINs are wrong. The proportion of suppliers with wrong TINs has remained high over the years as seen in Table 3.

Table 3 Cleanliness of suppliers' information in WHT returns

\begin{tabular}{lcccccc}
\hline Quality of suppliers' TINs & $\mathbf{2 0 1 5 / 1 6}$ & $\mathbf{2 0 1 6 / 1 7}$ & $\mathbf{2 0 1 7 / 1 8}$ & $\mathbf{2 0 1 8 / 1 9}$ & $\mathbf{2 0 1 9 / 2 0}$ & Total \\
\hline Correct TINs & $45 \%$ & $49 \%$ & $50 \%$ & $47 \%$ & $59 \%$ & $51 \%$ \\
\hline Wrong TINs & $55 \%$ & $51 \%$ & $50 \%$ & $53 \%$ & $41 \%$ & $49 \%$ \\
\hline Total & $100 \%$ & $100 \%$ & $100 \%$ & $100 \%$ & $100 \%$ & $100 \%$ \\
\hline
\end{tabular}

Source: Authors' own calculations from URA databases.

- The untraceable suppliers are actually making supplies worth billions of Uganda Shillings. For instance, suppliers with wrong TINs made supplies of UGX2,729.9bn in 2018/19 and UGX1,251.8bn in 2019/20, as seen in Figure 4 below. The increase in the number of suppliers and the value of supplies made in 2018/19 and then the drastic fall in 2019/20 is explained by the introduction of a 1 per cent withholding tax on agricultural supplies in 2018/19 and its abolition in 2019/20. 
Figure 4 Gross amount of supplies made by traceable and untraceable suppliers

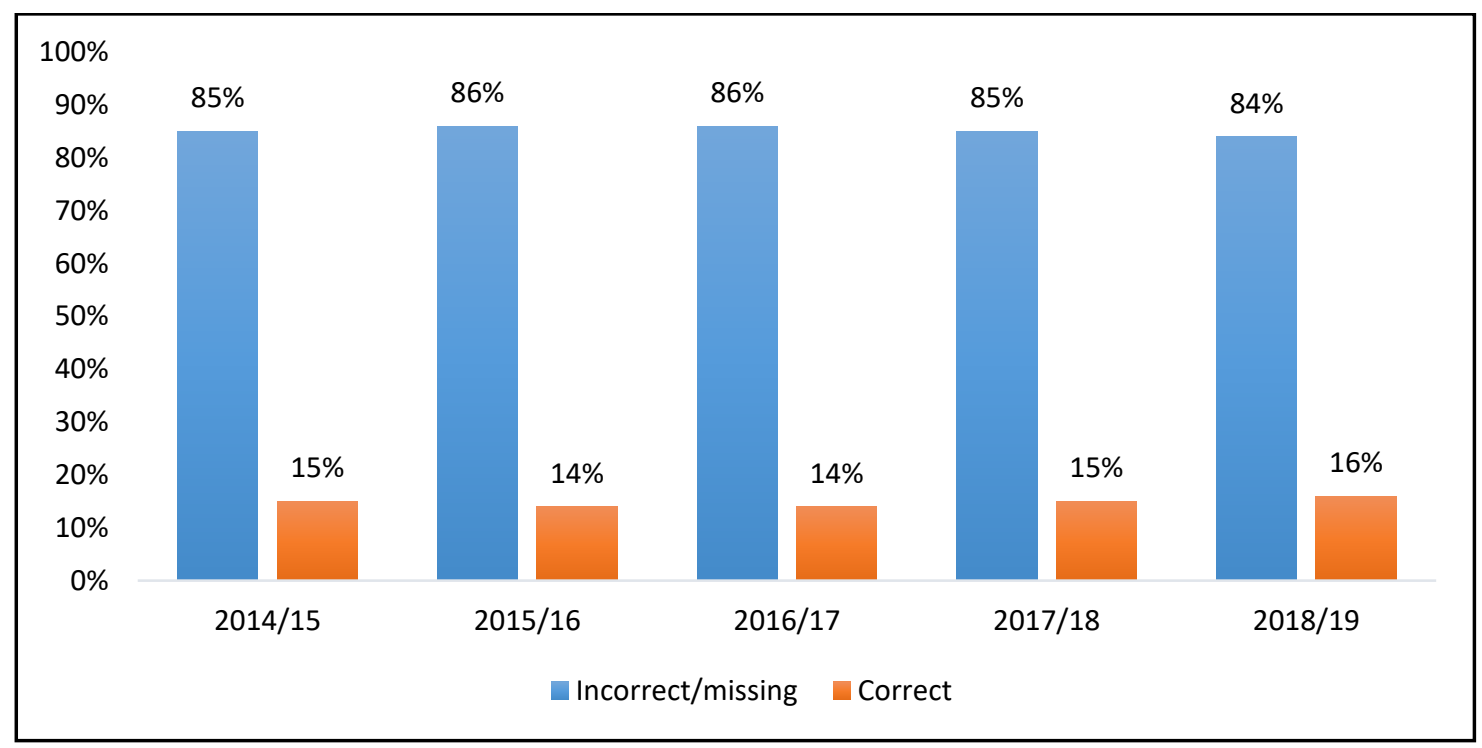

Source: Authors' own calculations from URA databases.

- Lastly, we also found that the unclean records in withholding tax returns are found in all segments of withholding tax agents - large, medium, small or government agencies.

\begin{tabular}{lcccccc}
\hline \multicolumn{7}{l}{ Table 4 Proportion of untraceable suppliers by size of withholding tax agent } \\
\hline WHT agent segment & $\mathbf{2 0 1 5 / 1 6}$ & $\mathbf{2 0 1 6 / 1 7}$ & $\mathbf{2 0 1 7 / 1 8}$ & $\mathbf{2 0 1 8 / \mathbf { 1 9 }}$ & $\mathbf{2 0 1 9 / 2 0}$ & Total \\
\hline LTO & $54 \%$ & $51 \%$ & $45 \%$ & $53 \%$ & $40 \%$ & $48 \%$ \\
\hline MTO & $64 \%$ & $64 \%$ & $62 \%$ & $55 \%$ & $46 \%$ & $56 \%$ \\
\hline PSO & $39 \%$ & $36 \%$ & $30 \%$ & $28 \%$ & $29 \%$ & $32 \%$ \\
\hline STO & $66 \%$ & $66 \%$ & $74 \%$ & $68 \%$ & $52 \%$ & $66 \%$ \\
\hline Total & $55 \%$ & $51 \%$ & $50 \%$ & $53 \%$ & $41 \%$ & $49 \%$ \\
\hline
\end{tabular}

Source: Authors' own calculations from URA databases.

\subsubsection{Value added tax return}

The VAT return form captures information about the taxpayer, and about sales and purchases of goods and services, differentiating whether the sales and purchases are zero rated, standard rated or exempt; whether the sales are local or exports; and whether the sales/purchases are capital goods or not. It also collects information on the applicable input and output VAT, ${ }^{13}$ deemed VAT, ${ }^{14}$ VAT deferments ${ }^{15}$ and offsets, ${ }^{16}$ among others. The output tax schedule for sales on which VAT is charged (schedule 1) requires the taxpayer to specify the registered name and TIN of the purchaser, invoice details (date, invoice number, description of goods or services and amount charged) and the applicable VAT charged. Similarly, the input tax schedule for local purchases on which VAT is incurred (schedule 2) requires the taxpayer to specify the name and TIN of the supplier, invoice details and the VAT incurred. Input tax incurred on imports is captured in schedule 3 . In this case, taxpayers are required to indicate the customs entry number for the case/s of goods, name of the

\footnotetext{
13 Input VAT is VAT paid by a registered person on purchases from another registered person while output VAT is VAT that is charged by a taxable person to customers in respect of taxable supplies.

14 Deemed VAT is when is VAT incurred but not paid, but the taxpayer is considered by URA to have paid it.

15 VAT deferments is VAT on imported plant and machinery that is postponed to be paid at a later date.

16 An offset occurs when output VAT is less than input VAT.
} 
supplier, source country of the goods, invoice details and the VAT incurred or deferred at importation.

We found that:

- All the identification information of purchasers and suppliers, i.e., the TINs and names declared in schedule 1 and schedule 2 respectively of the VAT returns, was complete and accurate. This is because while the TINs are not mandatory in the form, they are validated by e-tax upon uploading the completed forms. Any invalid or missing TIN of either a supplier or purchaser included in the VAT return form causes the entire return to be rejected by the system.

- However, the VAT return does not capture information on purchasers and suppliers that are not registered for VAT or those dealing in VAT exempted sales. All sales to unregistered clients, purchases from unregistered suppliers and sales of VAT exempt supplies are aggregated together. Yet these account for significant amounts in the returns. More than half (54 per cent) of all the VAT sales are to unregistered clients, as seen in Table 5. While it is understandable that identification details about unregistered suppliers, purchasers and those dealing in exempt supplies are not captured, since there are no input VAT claims by the respective players and also because most of them are likely to be small traders, some of these players may be dealing in huge supplies or purchases and, if identified, could help to expand the tax base. A threshold could for instance be set, such as sales or purchases to unregistered traders beyond UGX10m, where sufficient identification information for such large traders is captured.

Table 5 VAT sales to registered and unregistered clients

\begin{tabular}{lccc}
\hline Financial year & VAT sales to registered clients & Sales to unregistered clients & Sum of total sales \\
\hline $2015 / 16$ & $24,724.9$ & $29,440.8$ & $54,165.7$ \\
& $(46 \%)$ & $(54 \%)$ & $(100 \%)$ \\
\hline $2016 / 17$ & $27,779.1$ & $32,365.5$ & $60,144.5$ \\
& $(46 \%)$ & $(54 \%)$ & $(100 \%)$ \\
\hline $2017 / 18$ & $31,516.0$ & $35,666.8$ & $67,182.9$ \\
& $(47 \%)$ & $(53 \%)$ & $(100 \%)$ \\
\hline $2018 / 19$ & $33,773.2$ & $39,359.5$ & $73,132.7$ \\
& $(46 \%)$ & $(54 \%)$ & $(100 \%)$ \\
\hline $2019 / 20$ & $33,487.3$ & $38,342.1$ & $71,829.4$ \\
& $(47 \%)$ & $(53 \%)$ & $(100 \%)$ \\
\hline Grand total & $151,280.4$ & $175,174.7$ & $326,455.1$ \\
& $(46 \%)$ & $(54 \%)$ & $(100 \%)$ \\
\hline
\end{tabular}

Source: Authors' own calculations from URA databases.

- On the other hand, all customs entry numbers declared in schedule 3 on imports are either wrong or incomplete. Even when a complete entry number is recorded, the return form and e-tax system does not validate it with data in the customs ASYCUDA World system. A correct customs entry number should state a code for the station (tax office) where the entry was cleared, the year of clearance, the regime and a system generated series number. For example, 'UGBUS2020C1021' indicates that this entry was cleared from Busia border point in 2020 and the regime (C) is an import for home use. Most customs entry numbers specify only the regime and the system generated series numbers such as 'C1021' which can belong to various taxpayers cleared in different stations and/or in different years. It is therefore possible for taxpayers to claim input VAT on imports which they did not actually incur. For instance, in the November 2020 VAT 
return, 1,013 taxpayers indicated just a digit such as '0', '2', '9999' etc. as customs entry numbers.

\subsubsection{PAYE tax return gaps}

In the PAYE return form, schedule 1 requires the employer to indicate the identification details of each employee (names, TINs), period of employment, basic salary and the different types of allowances paid to each staff. The TIN is not a mandatory field but the employee's name, basic salary and period of employment are mandatory. Schedule 3 of the PAYE form captures information on lump sum payments relating to retirements, resignation, termination or expiry of employment, while schedule 4 captures information on annual/irregular/bonus payments. In both schedules 3 and 4, the employer is also required to include the identification details of the employees/beneficiaries, amounts paid and applicable PAYE deducted. None of the fields in schedules 3 and 4 are mandatory.

Because of the large datasets in PAYE returns, we only analysed the December return for different financial years. Results indicate that:

- The majority of the employers leave the field for employee TIN empty. As a result, any time series analysis of PAYE data at individual/employee level is difficult. The employee names are included but it is difficult to ascertain whether they are right or wrong as there is not any database that the e-tax can compare with to check the validity of the employee names included. There is also no standard way of writing names. In some cases, employers start with the first name and in other cases they start with the surname; some include initials, while others just include one name. In December 2020, 69 per cent of employees had missing TINs in the PAYE returns and only 30.5 per cent had accurate TINs included.

Table 6 Quality of employee TINs in the PAYE return

\begin{tabular}{lcc}
\hline Employee TINs & Number of employees & $\%$ share \\
\hline Included and correct & 243,742 & $30.54 \%$ \\
\hline Missing & 554,150 & $69.44 \%$ \\
\hline Included but wrong & 186 & $0.02 \%$ \\
\hline Total & $\mathbf{7 9 8 , 0 7 8}$ & $\mathbf{1 0 0 . 0 0 \%}$
\end{tabular}

Source: Authors' own calculations from URA databases.

- The quality of employee data in PAYE returns is improving. Considering the December returns for FY2014/15 to 2019/20, the proportion of employees in PAYE returns with missing/invalid TINs has reduced from 91 per cent in December 2015 to 69 per cent in December 2020.

Table 7 Wrong employee TINs in December PAYE returns 2014/15-2019/20

\begin{tabular}{lcccccc}
\hline Employee TINs & $\mathbf{2 0 1 4 / 1 5}$ & $\mathbf{2 0 1 5 / 1 6}$ & $\mathbf{2 0 1 6 / 1 7}$ & $\mathbf{2 0 1 7 / 1 8}$ & $\mathbf{2 0 1 8 / 1 9}$ & $\mathbf{2 0 1 9 / 2 0}$ \\
\hline Invalid/missing & $91 \%$ & $86 \%$ & $83 \%$ & $70 \%$ & $66 \%$ & $69 \%$ \\
\hline Valid & $9 \%$ & $14 \%$ & $17 \%$ & $30 \%$ & $34 \%$ & $31 \%$ \\
\hline Total & $\mathbf{1 0 0 \%}$ & $\mathbf{1 0 0 \%}$ & $\mathbf{1 0 0 \%}$ & $\mathbf{1 0 0 \%}$ & $\mathbf{1 0 0 \%}$ & $\mathbf{1 0 0 \%}$ \\
\hline $\begin{array}{l}\text { Number of } \\
\begin{array}{l}\text { employees } \\
\text { declared }\end{array}\end{array}$ & $\mathbf{4 0 0 , 0 5 3}$ & $\mathbf{5 7 2 , 4 2 6}$ & $\mathbf{6 3 9 , 6 9 1}$ & $\mathbf{6 9 1 , 1 5 2}$ & $\mathbf{7 4 0 , 8 6 1}$ & $\mathbf{7 9 8 , 0 7 8}$ \\
$\begin{array}{l}\text { Source: Authors' own calculations from URA databases. } \\
\text { Sour }\end{array}$ & & & & & \\
\hline
\end{tabular}

- The improvements in the quality of employee information are realised in all taxpayer segments starting from $2017 / 18$, except public sector institutions, where the 
improvements are observed since $2014 / 15$, mainly attributed to the introduction of a specialised tax office (PSO) for government entities in September 2014. When the PSO was created, the team engaged the Permanent Secretary and Secretary to the Treasury (PSST) at the Ministry of Finance, Planning and Economic Development who supported them by directing all the accounting officers of government agencies to comply with their tax obligations. Organisations that failed to comply risked missing budget funding; accounting officers also risked losing their jobs (Saka, Waiswa and Kangave 2018). The PSST also directed all government employees to have a TIN before they could be paid their monthly salaries. In 2017, URA also undertook an administrative measure tasking employers to include employee TINs in their PAYE returns (interview with PSO tax officer). As seen in Figure 5 below, taxpayers in the LTO are responding more to this URA directive than are other taxpayer segments.

\section{Figure 5 Proportion of invalid employee TINs by employer size}

\begin{tabular}{|c|c|c|c|c|c|c|c|}
\hline \multicolumn{8}{|l|}{$120 \%$} \\
\hline \multicolumn{8}{|l|}{$100 \%$} \\
\hline \multicolumn{8}{|l|}{$80 \%$} \\
\hline \multicolumn{8}{|l|}{$40 \%$} \\
\hline \multicolumn{8}{|l|}{$20 \%$} \\
\hline $0 \%$ & $2013 / 14$ & $2014 / 15$ & $2015 / 16$ & $2016 / 17$ & $2017 / 18$ & $2018 / 19$ & $2019 / 20$ \\
\hline LTO & $93 \%$ & $91 \%$ & $91 \%$ & $91 \%$ & $68 \%$ & $58 \%$ & $58 \%$ \\
\hline MTO & $96 \%$ & $95 \%$ & $95 \%$ & $95 \%$ & $70 \%$ & $69 \%$ & $69 \%$ \\
\hline$\longrightarrow$ PSO & $73 \%$ & $83 \%$ & $71 \%$ & $66 \%$ & $61 \%$ & $69 \%$ & $69 \%$ \\
\hline STO & $96 \%$ & $95 \%$ & $95 \%$ & $94 \%$ & $80 \%$ & $80 \%$ & $80 \%$ \\
\hline
\end{tabular}

Source: Authors' own calculations from URA databases.

\subsubsection{Income tax return gaps}

In the income tax return form, section $D$ requires that identification information about the directors and major shareholders is included, such as a TIN, name, designation (job title) and address. These variables are not mandatory in the form and are not validated in e-tax.

However, when a company is registering to receive a TIN, all the directors are required to already have valid TINs for the company TIN to be approved. An assessment of the quality of TINs declared in income tax return forms indicated that in 2014/15, 3,560 (18 per cent) of company directors declared in income tax returns could not be easily traced as their TINs were invalid. The share of the invalid directors' TINs is decreasing over the years, but marginally, as seen in Table 8 below.

Table 8 Quality of company directors' TINs in income tax returns

\begin{tabular}{|l|c|c|c|c|c|c|}
\hline Company director TINs & $\mathbf{2 0 1 4} / \mathbf{1 5}$ & $\mathbf{2 0 1 5} / \mathbf{1 6}$ & $\mathbf{2 0 1 6 / 1 7}$ & $\mathbf{2 0 1 7 / 1 8}$ & $\mathbf{2 0 1 8} / \mathbf{1 9}$ & Total \\
\hline Invalid & $3,560(18 \%)$ & $3,436(17 \%)$ & $3,053(15 \%)$ & $3,024(14 \%)$ & $2,760(13 \%)$ & $15,833(15 \%)$ \\
\hline Valid & $15,868(82 \%)$ & $16,974(83 \%)$ & $17,256(85 \%)$ & $17,933(86 \%)$ & $18,509(87 \%)$ & $86,540(85 \%)$ \\
\hline Total & $\mathbf{1 9 , 4 2 8}$ & $\mathbf{2 0 , 4 1 0}$ & $\mathbf{2 0 , 3 0 9}$ & $\mathbf{2 0 , 9 5 7}$ & $\mathbf{2 1 , 2 6 9}$ & $\mathbf{1 0 2 , 3 7 3}$ \\
\hline
\end{tabular}

Source: Authors' own calculations from URA databases. 
Analysis of the income tax returns for 2018/19 also indicated a few cases of taxpayers declaring outrightly fraudulent information. For instance, 284 taxpayers declared no loans but indicated interest expenses on loans worth a total of UGX86.89bn. Some taxpayers declared interests which were more than the loan amount. There were 62 taxpayers who declared interest expenses that were more than 200 per cent of the loan amount. One taxpayer, for example, declared a loan of only UGX32m but claimed interest expenses of UGX1.87bn. We also found 50 taxpayers in 2018/19 with a negative cost of sales in their annual returns. This implies that when we added up their opening stock at the start of the year and the purchases made during the year, the total was less than their closing stock.

\subsection{Consistency of information submitted in tax returns}

We assessed the extent to which taxpayers submit similar information in cases where the same information is required in different types of tax returns, or submitted in the same type of tax return, but for different time periods; or in the same return, but in different parts of the form; or submitted to different systems, such as the customs information in ASYCUDA World that is required in domestic tax returns (mainly income tax and VAT returns) in e-tax.

We found that:

a) Even in the same return, when the same information is expected at different points in the return form, a few taxpayers declare inconsistent values. For instance, in the income tax return, taxpayers are required to state the total inventory at the end of the year in the balance sheet under section $D$ of the return form and closing stock in the profit and loss account under section E. On average, about 7 per cent of the returns submitted every year have inconsistent values in these two columns.

Table 9 Inconsistency between closing stock and inventory in the same return

\begin{tabular}{lccccc}
\hline Row labels & $\mathbf{2 0 1 4 / 1 5}$ & $\mathbf{2 0 1 5 / 1 6}$ & $\mathbf{2 0 1 6 / 1 7}$ & $\mathbf{2 0 1 7 / 1 8}$ & $\mathbf{2 0 1 8 / 1 9}$ \\
\hline Consistent & 29,944 & 37,169 & 38,756 & 42,701 & 46,320 \\
& $(91 \%)$ & $(92 \%)$ & $(93 \%)$ & $(94 \%)$ & $(94 \%)$ \\
\hline Inconsistent & 3,136 & 3,223 & 3,086 & 2,825 & 2,713 \\
& $(9 \%)$ & $(8 \%)$ & $(7 \%)$ & $(6 \%)$ & $(6 \%)$ \\
\hline Total & 33,080 & 40,392 & 41,842 & 45,526 & 49,033 \\
& $(100 \%)$ & $(100 \%)$ & $(100 \%)$ & $(100 \%)$ & $(10 \%)$ \\
\hline
\end{tabular}

Source: Authors' own calculations from URA databases.

b) In cases where the same tax return type is submitted at different periods but similar information is ideally required in both returns, such as closing stock at the end of the year in the income tax return and opening stock declared for the subsequent year, or VAT offsets carried forward, some taxpayers also declare inconsistent values.

Specifically:

- In the income tax returns, there are some taxpayers who declare inconsistent values in regard to closing stock in one year and opening stock for the subsequent year. The proportion of the returns declared with inconsistent values is however observed to decline by one percentage point each financial year from 6 per cent in 2014/15, when the closing stock of 2013/14 was compared with the opening stock of 2014/15, to 3 per cent in 2018/19. The few cases of inconsistent returns as seen in Table 10 below are in part a result of the e-tax validation check on the consistency of closing stock and opening stock. The e-tax system automatically flags up returns with inconsistent values for the risk assessment team to follow up with the taxpayers. Results also indicated that more than half of the taxpayers are either inconsistent filers of income tax returns or deliberately leave the column of opening stock or closing stock blank in their tax returns. For instance, 
when we compared the opening stock in 2018/19 returns with closing stock declared in $2017 / 18$ returns, we found 55 per cent had one of the two values missing.

Table 10 Consistency of opening stock and closing stock in income tax returns

\begin{tabular}{|c|c|c|c|c|c|}
\hline $\begin{array}{l}\text { Consistency of opening and closing } \\
\text { stock }\end{array}$ & $\begin{array}{c}2013 / 14 \& \\
2014 / 15\end{array}$ & $\begin{array}{c}2014 / 15 \& \\
2015 / 16\end{array}$ & $\begin{array}{c}2015 / 16 \& \\
2016 / 17\end{array}$ & $\begin{array}{c}2016 / 17 \& \\
2017 / 18\end{array}$ & $\begin{array}{c}2017 / 18 \& \\
2018 / 19\end{array}$ \\
\hline Consistent & $52 \%$ & $47 \%$ & $42 \%$ & $41 \%$ & $43 \%$ \\
\hline $\begin{array}{l}\text { Either opening stock or closing stock not } \\
\text { declared/missing }\end{array}$ & $42 \%$ & $48 \%$ & $54 \%$ & $56 \%$ & $55 \%$ \\
\hline Inconsistent & $6 \%$ & $5 \%$ & $4 \%$ & $3 \%$ & $2 \%$ \\
\hline Grand total & $100 \%$ & $100 \%$ & $100 \%$ & $100 \%$ & $100 \%$ \\
\hline Total number of returns & 41,807 & 58,131 & 87,429 & 11,7565 & 12,9874 \\
\hline
\end{tabular}

Source: Authors' own calculations from URA databases.

- Considering taxpayers that declare losses in their income tax return and comparing that to the amount of loss carried forward in their return for the subsequent year, we found that more than half of them declare inconsistent values. Surprisingly, of those that declare inconsistent values, the majority declare a loss that is less than the value they declared in the previous year's return. For instance, in 2017/18 and 2018/19, of the 11,847 taxpayers who declared a loss, only 28 per cent carried forward a value in their $2018 / 19$ return that was consistent with their loss carried forward from 2017/18. Fifty-six per cent declared an inconsistent value: 47 per cent declared a carried forward loss in 2018/19 than was less than the loss they had reported in 2017/18, and 9 per cent carried forward a higher loss than they had reported in $2017 / 8$.

Table 11 Consistency of carried forward losses in income tax returns Consistency of end of year losses carried forward $\quad 2013 / 14 \& \quad 2014 / 15 \& \quad 2015 / 16 \& \quad 2016 / 17 \& \quad 2017 / 18$ \& $2014 / 15 \quad 2015 / 16 \quad 2016 / 17 \quad 2017 / 18 \quad 2018 / 19$

\begin{tabular}{lrrrrr}
\hline Consistent & $33 \%$ & $35 \%$ & $37 \%$ & $38 \%$ & $29 \%$ \\
\hline $\begin{array}{l}\text { Declared more carried forward losses than the loss they } \\
\text { declared at the end of previous year }\end{array}$ & $8 \%$ & $8 \%$ & $8 \%$ & $7 \%$ & $9 \%$ \\
\hline $\begin{array}{l}\text { Declared less carried forward losses than the loss they } \\
\text { declared at the end of previous year }\end{array}$ & $45 \%$ & $44 \%$ & $48 \%$ & $49 \%$ & $47 \%$ \\
\hline $\begin{array}{l}\text { Did not file subsequent year return } \\
\text { Total number of returns with loss at end of year }\end{array}$ & $14 \%$ & $13 \%$ & $7 \%$ & $6 \%$ & $15 \%$ \\
\hline
\end{tabular}

Source: Authors' own calculations from URA databases.

- We also identified 1,492 taxpayers who indicated large amounts on land and buildings in their 2017/18 income tax return but declared zero or left the field missing in 2018/19 return, yet did not indicate that they had disposed of the assets. Similarly, for those who declared the value of land and buildings in both their 2017/18 and their 2018/19 returns, 65 taxpayers declared that the value of their land and/or buildings had reduced by more than 50 per cent. For instance, one declared the value to be UGX187.7bn in 2017/18 and only UGX164m in 2018/19 but did not declare any value for disposal of assets.

- We also looked at inconsistencies in VAT return information. We compared the VAT offsets ${ }^{17}$ declared in the December returns of various years with the amount of VAT offsets carried forward in the January returns. Results indicate that there are a few VAT taxpayers (roughly 9 per cent) submitting inconsistent values. In the January 2020 returns, for instance, while the majority (92 per cent) of the VAT taxpayers with offsets in December 2019 carried forward a consistent value in the January 2020 return, 4 per cent claimed a VAT offset in January although they did not have one in their December return. Similarly, 4 per cent carried forward an inconsistent value with 2 per cent carrying forward

A VAT offset return is one where the output VAT is less than the input VAT. In this case the taxpayer is supposed to be refunded the difference or can decide to carry forward the difference to be used to offset his/her VAT liability for the next period. 
higher offsets than the ones they declared in December returns and another 2 per cent carrying forward a lower value, as seen in Table 12 below.

Table 12 Consistency of VAT offsets carried forward in January returns from

\section{December returns}

\begin{tabular}{|c|c|c|c|c|}
\hline $\begin{array}{l}\text { Consistency of VAT offsets carried forward } \\
\text { in January returns from December returns }\end{array}$ & Jan-17 & Jan-18 & Jan-19 & Jan-20 \\
\hline Consistent & $\begin{array}{l}3,486 \\
(91 \%)\end{array}$ & $\begin{array}{l}3,553 \\
(90 \%)\end{array}$ & $\begin{array}{l}3,624 \\
(90 \%)\end{array}$ & $\begin{array}{l}3,228 \\
(92 \%)\end{array}$ \\
\hline Higher offsets & $\begin{array}{r}79 \\
(2 \%)\end{array}$ & $\begin{array}{r}90 \\
(2 \%)\end{array}$ & $\begin{array}{r}85 \\
(2 \%)\end{array}$ & $\begin{array}{r}62 \\
(2 \%)\end{array}$ \\
\hline Lower offsets & $\begin{array}{r}90 \\
(2 \%)\end{array}$ & $\begin{array}{r}103 \\
(3 \%)\end{array}$ & $\begin{array}{r}67 \\
(2 \%) \\
\end{array}$ & $\begin{array}{r}68 \\
(2 \%) \\
\end{array}$ \\
\hline Claimed offset yet did not have one in previous month & $\begin{array}{r}172 \\
(5 \%)\end{array}$ & $\begin{array}{r}180 \\
(5 \%)\end{array}$ & $\begin{array}{r}226 \\
(6 \%)\end{array}$ & $\begin{array}{r}157 \\
(4 \%)\end{array}$ \\
\hline Total & $\begin{array}{r}3,827 \\
(100 \%)\end{array}$ & $\begin{array}{r}3,926 \\
(100 \%)\end{array}$ & $\begin{array}{r}4,002 \\
(100 \%)\end{array}$ & $\begin{array}{r}3,515 \\
(100 \%)\end{array}$ \\
\hline
\end{tabular}

Source: Authors' own calculations from URA databases.

c) Some taxpayers submit inconsistent information in cases where the same information is required in different tax type returns.

In 2018/19, 764 taxpayers declared nil income tax returns, meaning they had no turnover declared, yet they were declared in withholding tax returns as suppliers, with some making supplies worth billions of Uganda Shillings. There were also 55 companies that claimed for management fees expenses in their 2017/18 tax returns, yet did not declare such services in their withholding tax returns. In total, these 55 companies claimed management fees expenses of UGX125.8bn without any withholding tax deducted on such services.

\section{d) Inconsistencies between tax returns data and registration data.}

At registration, all companies are required to declare their directors and partners. For the company TIN to be approved, these directors must be the same as those registered with the Uganda Registration Service Bureau (URSB) on company forms 7, 8 and, for those which are partnerships, on the partnership deed. Similarly, when filing the company annual income tax return, companies are required to declare their directors and partners. In 2018/19, a total of 98,119 companies under declared the number of directors in their income tax returns compared to the number of directors on their registration profile. In total, 174,123 directors were not declared in the submitted income tax returns, yet they were reflected on the companies' registration profiles.

In 2018/19 5,303 taxpayers claimed employee compensation expenses in their income tax returns but were not registered for PAYE.

\section{e) Inconsistencies between tax return data and customs data in the ASYCUDA World system.}

Comparing VAT charged on imports with the input VAT on imports declared in VAT returns for 2018/19, we found that of the 40,556 importers studied, 812 declared more input VAT in their VAT returns than what they were actually charged at the point of importation. In total, the variance was UGX94.4bn wrongly claimed as input VAT from imports.

We also compared VAT deferments at customs with the amounts of deferred VAT declared in VAT returns. In 2018/19, 210 taxpayers were granted an incentive to defer VAT on plant and machinery. However, for 192 taxpayers, the amounts of VAT deferred at customs and the amount they declared in their VAT returns did not match. Only 18 taxpayers declared the same amounts of deferred VAT in their VAT returns. Similarly, in 2019/20, of the 175 
taxpayers that were granted VAT deferment, 151 reported inconsistent values in their VAT returns.

Lastly, within the customs data we found a number of potential taxpayers who are not registered for domestic taxes such as income tax. To be eligible for income tax payment, one needs to have a minimum turnover of at least UGX10m (the lowest threshold for presumptive tax). We observed that for $2018 / 19$ over 1,346 taxpayers imported goods with a value of more than UGX10m, and others even imported goods worth billions of UGX, yet they are not registered for income tax.

Table 13 Importers not registered for income tax FY 2018/19

\begin{tabular}{lcc}
\hline Value of imports & Number of importers & $\%$ share \\
\hline Greater than 1bn & 9 & $1 \%$ \\
\hline $500 \mathrm{~m}-1 \mathrm{bn}$ & 26 & $2 \%$ \\
\hline $150 \mathrm{~m}-500 \mathrm{~m}$ & 105 & $8 \%$ \\
\hline $10 \mathrm{~m}-150 \mathrm{~m}$ & 1,206 & $88 \%$ \\
\hline Less than $10 \mathrm{~m}$ & 20 & $1 \%$ \\
\hline Grand total & $\mathbf{1 , 3 6 6}$ & $\mathbf{1 0 0 \%}$ \\
\hline
\end{tabular}

Source: Authors' own calculations from URA databases.

\subsection{Permanence of tax return information}

We assessed the extent to which returns are likely to be later modified by the taxpayer. We found that the returns that are amended the most are income tax and VAT returns. While most of the amended returns are by small taxpayers, by taxpayer segment, higher proportions of large and medium taxpayers amend their returns. For PAYE and withholding tax returns, large taxpayers and public sector taxpayers (government agencies) amend the most.

More specifically:

- For income tax returns, on average, about 26 per cent of the submitted returns by large taxpayers are amended. Similarly, over 23 per cent of returns submitted by medium taxpayers are amended, but only around 12 per cent of the income tax returns submitted by small taxpayers are amended. The low proportion of income tax amendments by small taxpayers could in part be due to the fact that most of them do not file real regime income tax returns. The bulk of them are taxed under the presumptive tax regime.

Table 14 Proportion of amended income tax returns

\begin{tabular}{|c|c|c|c|c|c|c|c|c|c|c|c|c|c|c|c|}
\hline \multirow[b]{2}{*}{ Segment } & \multicolumn{6}{|c|}{ Number of income tax returns filed } & \multicolumn{5}{|c|}{ Number of returns amended } & \multicolumn{4}{|c|}{ Proportion of returns amended } \\
\hline & $\begin{array}{c}2014 / \\
15\end{array}$ & $\begin{array}{c}2015 / \\
16\end{array}$ & $\begin{array}{c}2016 / \\
17\end{array}$ & 2017/18 & $2018 / 19$ & $\begin{array}{c}2014 / \\
15\end{array}$ & $\begin{array}{c}2015 / \\
16\end{array}$ & $\begin{array}{c}2016 / \\
17\end{array}$ & $\begin{array}{c}2017 / \\
18\end{array}$ & $\begin{array}{c}2018 / \\
19\end{array}$ & $\begin{array}{c}2014 / \\
15\end{array}$ & $\begin{array}{c}2015 / \\
16\end{array}$ & $\begin{array}{c}2016 / \\
17\end{array}$ & $\begin{array}{c}2017 / \\
18\end{array}$ & $\begin{array}{c}2018 / \\
19\end{array}$ \\
\hline LTO & 1,078 & 981 & 970 & 1,041 & 1,095 & 250 & 239 & 272 & 292 & 262 & $23 \%$ & $24 \%$ & $28 \%$ & $28 \%$ & $24 \%$ \\
\hline MTO & 2,344 & 2,278 & 2,103 & 2,056 & 1,978 & 538 & 529 & 496 & 545 & 403 & $23 \%$ & $23 \%$ & $24 \%$ & $27 \%$ & $20 \%$ \\
\hline Sто & 40,344 & 56,408 & 81,903 & 103,417 & 107,798 & 6,708 & 6,584 & 8,025 & 11,733 & 11,513 & $17 \%$ & $12 \%$ & $10 \%$ & $11 \%$ & $11 \%$ \\
\hline
\end{tabular}

Source: Authors' own calculations from URA databases.

- Similarly, higher proportions of VAT returns submitted by large and medium taxpayers are amended. In 2018/19 for instance, 35 per cent and 27 per cent of VAT returns by large and medium taxpayers respectively were amended while only 18 per cent of the returns by small taxpayers were amended. It is most likely that the low proportions of 
amended VAT returns among small taxpayers and public sector taxpayers is a result of the fact that few of them are registered for VAT.

- For PAYE and WHT returns, the proportion of amended returns is a bit lower. Fewer than 15 per cent of PAYE and withholding returns are amended. The proportion of PAYE and WHT returns amended is highest among LTO and PSO taxpayers, as seen in Table 15.

Table 15 Proportion of amended VAT, PAYE and withholding tax returns

\begin{tabular}{|c|c|c|c|c|c|}
\hline & \multicolumn{5}{|c|}{$\%$ of returns amended } \\
\hline Tax type & Segment & $2015 / 16$ & $2016 / 17$ & $2017 / 18$ & $2018 / 19$ \\
\hline \multirow{5}{*}{ Value added tax } & LTO & $30 \%$ & $24 \%$ & $30 \%$ & $35 \%$ \\
\hline & MTO & $25 \%$ & $23 \%$ & $27 \%$ & $27 \%$ \\
\hline & STO & $17 \%$ & $16 \%$ & $17 \%$ & $18 \%$ \\
\hline & Average & $24 \%$ & $21 \%$ & $25 \%$ & $27 \%$ \\
\hline & STO & $17 \%$ & $16 \%$ & $17 \%$ & $18 \%$ \\
\hline & & $2015 / 16$ & $2016 / 17$ & $2017 / 18$ & $2018 / 19$ \\
\hline \multirow{6}{*}{ PAYE } & LTO & $11 \%$ & $10 \%$ & $23 \%$ & $22 \%$ \\
\hline & MTO & $9 \%$ & $8 \%$ & $9 \%$ & $7 \%$ \\
\hline & STO & $6 \%$ & $5 \%$ & $5 \%$ & $6 \%$ \\
\hline & PSO & $16 \%$ & $25 \%$ & $18 \%$ & $18 \%$ \\
\hline & Average & $10 \%$ & $12 \%$ & $14 \%$ & $13 \%$ \\
\hline & & $2015 / 16$ & $2016 / 17$ & $2017 / 18$ & $2018 / 19$ \\
\hline \multirow{5}{*}{ Withholding tax } & LTO & $19 \%$ & $18 \%$ & $30 \%$ & $26 \%$ \\
\hline & MTO & $11 \%$ & $9 \%$ & $11 \%$ & $12 \%$ \\
\hline & STO & $6 \%$ & $6 \%$ & $6 \%$ & $6 \%$ \\
\hline & PSO & $18 \%$ & $23 \%$ & $22 \%$ & $20 \%$ \\
\hline & Average & $14 \%$ & $14 \%$ & $17 \%$ & $16 \%$ \\
\hline
\end{tabular}

Source: Authors' own calculations from URA databases.

- Lastly, while most of the returns are amended once, we found a few cases of taxpayers amending the same return several times. There are cases where a taxpayer amends the same return as many as six times. Some of the taxpayers who amended their returns several times were observed to be adjusting variables that would lower their tax liability. For instance, we studied a taxpayer who amended a PAYE return for January 2020 six times and observed huge inconsistences in the amounts of gross salaries and the number of employees declared in the different amendments. In the original return, the taxpayer indicated that the company paid gross salaries of UGX18.32m to 20 employees. The return was then amended to reflect only salaries of UGX3.1m and two employees. He then further amended the salaries to only UGX0.45m and the number of employees to just one. By the sixth amendment, the figure for gross salaries was UGX1.08m and the number of employees was two. Another taxpayer that amended his VAT return five times exhibited similar fraudulent tendencies where he kept adjusting the VAT offset amount, from UGX2.58m in the original return, to UGX3.87m, and finally to UGX4.01m in the fifth amendment. URA therefore needs to pay extra attention to taxpayers who are amending their returns several times.

\subsection{What explains the high rates of tax return amendments, especially for income tax?}

Firstly, Section 23(3) of the Tax Procedures Code Act (TPC) allows taxpayers upon discovering an error to amend their tax returns within 12 months of furnishing the return. The section however requires that the taxpayer should first apply to the commissioner who is required under sub section 4 to notify the taxpayer in writing within 30 days about his/her 
decision as to whether the taxpayer's application to amend a return is granted or not. Practically, however, the requirement to apply to the commissioner before a return is amended is not followed and URA does not enforce it either. As a result, taxpayers freely amend their returns any number of times without written approval from URA.

Administratively, URA allows taxpayers to amend their returns within a period of three years. This was initiated after the introduction of a self-health check initiative where taxpayers are asked to audit themselves before URA performs an audit on them (interview with official in business policy division).

We studied the reasons given for amendment of income tax returns in 2018/19. E-tax requires taxpayers amending returns to state the reason. Most stated that they were now filing the 'actual return' either because their first submission was a nil return, or had missing information, or that at the time of submitting the return their audited books of accounts were not ready. The implication is that the taxpayers were filing the first return to meet the filing deadline and avoid penalties for late filing.

There were however also a good number of taxpayers who stated that they had noticed some errors in their original submission and so were correcting these, while a few taxpayers included reasons such as: (a) changing to the real regime income tax after they had wrongly filed a presumptive tax return; (b) amending their return after being advised to do so by URA auditors; and (c) that they had originally uploaded a wrong file.

\section{Causes of the data gaps in taxpayer returns}

The data gaps listed above are a result of a number of causes and challenges. The causes include (a) people-related causes including taxpayers, tax agents, URA officers and management; (b) the complexity of the return forms; (c) gaps in the return forms; (d) weakness in the e-tax system and low levels of system integrations; and (d) weak tax return management processes. We discuss each of these below.

\subsection{People-related causes}

The people-related causes include those related to taxpayers and tax agents as well as those related to URA staff including senior management in the domestic taxes department.

From the taxpayer side, there are three main causes of errors in tax returns. First and most importantly is that, most of the time, the returns are filed in a rush, mainly to meet filing deadlines in order to avoid penalties for late filing. Second is that there is generally low tax knowledge, and third is taxpayer dishonesty. In our survey, we asked taxpayers the main causes of errors in tax returns. Of the 818 taxpayers who responded to the question, 28 per cent stated that the errors are mainly because the returns are filed towards the deadline and 21 per cent said the returns are filed to just meet the deadline in order to avoid penalties. As a result, as taxpayers are struggling to meet the deadlines, they end up submitting incomplete, inaccurate and inconsistent data. 
Table 16 Taxpayer opinions on the causes of errors in tax returns

\begin{tabular}{lrr}
\hline Causes of errors in tax returns & Frequency & $\%$ share \\
\hline Taxpayers filing towards the deadline & 229 & $28 \%$ \\
\hline Taxpayers finding tax returns complicated to complete & 220 & $27 \%$ \\
\hline Taxpayers filing to just meet deadlines in order to avoid penalties & 169 & $21 \%$ \\
\hline Taxpayer dishonesty & 21 & $3 \%$ \\
\hline Low tax knowledge & 25 & $3 \%$ \\
\hline Other & 154 & $19 \%$ \\
\hline Total & 818 & $100 \%$
\end{tabular}

Source: Survey responses.

Administrative data at URA indeed indicates that most tax returns are submitted towards the deadline. For instance, while taxpayers have up to six months to file an income tax return, 75 per cent of them file the income tax return in the last ten days of the last month, with 44 per cent filing on either the very last day or the second last day of the month.

Table 17 Timeliness of income tax return filing

\begin{tabular}{lcc}
\hline Dates when the income tax returns are filed & Number of filers & $\%$ share \\
\hline Before the $20^{\text {th }}$ of the last month & 5,336 & $25 \%$ \\
\hline $20^{\text {th }}-29^{\text {th }}$ & 6,510 & $31 \%$ \\
\hline $30^{\text {th }}-31^{\text {st }}$ & 9,259 & $44 \%$ \\
\hline Total & 21,105 & $100 \%$
\end{tabular}

Source: Authors' own from URA databases.

Similarly, even for the monthly returns (PAYE, VAT and WHT) that are supposed to be filed by the $15^{\text {th }}$ day of the month, most taxpayers file on the last day or within the last three days, as seen in Table 18. 
Table 18 Timeliness of monthly VAT, PAYE and WHT return filing

\begin{tabular}{|c|c|c|c|}
\hline \multirow{2}{*}{ Day when the returns are filed } & PAYE & VAT & WHT \\
\hline & $\mathrm{N}=197,984$ & $\mathrm{~N}=171,634$ & $\mathrm{~N}=35,054$ \\
\hline Day 1 & $0 \%$ & $1 \%$ & $1 \%$ \\
\hline Day 2 & $1 \%$ & $1 \%$ & $2 \%$ \\
\hline Day 3 & $1 \%$ & $1 \%$ & $2 \%$ \\
\hline Day 4 & $1 \%$ & $1 \%$ & $2 \%$ \\
\hline Day 5 & $2 \%$ & $2 \%$ & $3 \%$ \\
\hline Day 6 & $3 \%$ & $2 \%$ & $3 \%$ \\
\hline Day 7 & $3 \%$ & $3 \%$ & $4 \%$ \\
\hline Day 8 & $4 \%$ & $3 \%$ & $4 \%$ \\
\hline Day 9 & $4 \%$ & $3 \%$ & $4 \%$ \\
\hline Day 10 & $6 \%$ & $5 \%$ & $6 \%$ \\
\hline Day 11 & $9 \%$ & $7 \%$ & $9 \%$ \\
\hline \multicolumn{4}{|c|}{$\operatorname{Day} 12-------------11 \%------9 \%-----11 \%--$} \\
\hline Day 13 & $14 \%$ & $13 \%$ & $14 \%$ \\
\hline Day 14 & $18 \%$ & $19 \%$ & $17 \%$ \\
\hline----- & $22 \%$ & $30 \%$ & $19 \%$ \\
\hline Grand total & $100 \%$ & $100 \%$ & $100 \%$ \\
\hline
\end{tabular}

Source: Authors' own from URA databases.

Secondly, while only a few taxpayers suggested that some errors are a result of taxpayer dishonesty, our assessment suggests that for a few taxpayers, some errors - such as declaring incorrect identification details for company directors, or, in the case of landlords, for tenants - are deliberate. This could be because of either a deliberate effort to under report tax liability or an 'I don't care' attitude. Lastly, low tax knowledge appears to be an issue for some taxpayers. In the survey, we asked taxpayers who is responsible for filing their tax returns. Of the 850 that responded to the question, 47 per cent said their employee/accountant files the returns and 32 per cent stated that it is done by a tax agent/consultant, while only 21 per cent said they do it themselves. We also asked, 'If a return is not filed by yourself, do you take time to review the filled in information before the return is submitted to URA?' About 28 per cent of those who do not file their returns themselves said they do not review the return filled by either their accountant or tax agent before it is submitted to URA. Lastly, we asked for the reasons as why they do not review their return. Most (57 per cent) stated that it is because they trust their accountant/tax agent to do the right thing, 37 per cent said it is because they don't know what to do, while 6 per cent said they do not have time to review returns. Other reasons for not reviewing returns included having challenges with English, since all returns are to be completed in English, and that most of the time the returns are submitted at the last moment.

Tax agents/consultants are part of the problem. Some are not professional in their work. In one interview, the taxpayer said:

At first, I used to trust the agent but later found out that they had changed some figures without my consent because they wanted the figures to balance. This caused me a lot of problems to convince the URA officer as I had been imposed on a heavy tax 
assessment. However, at last when I raised my explanation, the tax was cancelled, and I learnt a lesson.

On the part of URA staff, there are two main cause of data gaps in tax returns: the fear of the management team in the domestic taxes department of having to implement strict validation checks on the forms, and negligence by tax officers. When e-tax had just been piloted, management decided to limit the restrictions/validations on all tax returns as a way of encouraging taxpayers to easily transition from the manual process to the electronic environment. Their fear was that if there were many restrictions, many returns would be rejected by the system, frustrating many taxpayers who would thus end up not filing their returns. While more restrictions/validations have been implemented over time, management is still hesitant to implement some key validation checks because of the same fear that taxpayers will end up not complying with filing their returns. For instance, while the Income Tax Act requires that taxpayers that declare any suppliers (individuals or companies) who provide them with supplies of at least UGX1m must include these suppliers' TINs, URA is yet to implement this. Similarly, the TINs of company directors in income tax returns, the TINs of landlords and tenants in rental returns, etc. are not validated by the e-tax system, but this same system does validate suppliers and purchasers in VAT returns. In the end, because taxpayers know that this information will not be validated, many taxpayers end up supplying wrong identification details about company directors, landlords and tenant which would have been useful in identifying potential taxpayers.

Some URA staff are also negligent. Even when there were verification and approval processes, a number of staff were just approving returns without sufficient scrutiny of the submitted information (response from tax officials). In part, this was because they were appraised based on the number of returns approved and any delayed returns would be red flagged in their login accounts.

\subsection{Complexity of return forms}

Some tax return forms, particularly the income tax and VAT returns, are perceived as complex to complete. From the survey, more than half (58 per cent) of the taxpayers said it is very difficult to complete the income tax return and 29 per cent said the VAT return is complex to complete. For the income tax return, taxpayers said it is very technical to understand and thus can only be completed by a professional accountant; that it requires the completion of many fields, most of which are not applicable to their type of businesses; and that it is difficult to determine the taxable and non-taxable expenses. PAYE returns are the easiest to complete. About 75 per cent of the respondents said it is easy to complete a PAYE return while only 10 per cent find it to be very difficult. The few that said it is very difficult mainly stated that the form requires them to fill in the same list of employees every month and suggested that perhaps the list of their employees could be stored on e-tax so that when they log in to fill their PAYE returns, the names of the employees are auto-populated for them to just review and amend where necessary.

Table 19 Ease of filing different tax returns

\begin{tabular}{lrrrr}
\hline Tax head & Easy & Very difficult & Don't know & \multicolumn{2}{c}{ Grand total } \\
\hline Income tax & 199 & 426 & 111 & 736 \\
& $(27 \%)$ & $(58 \%)$ & $(15 \%)$ & $(100 \%)$ \\
\hline VAT & 281 & 172 & 136 & 589 \\
& $(48 \%)$ & $(29 \%)$ & $(23 \%)$ & $(100 \%)$ \\
\hline PAYE & 458 & 58 & 91 & 607 \\
& $(75 \%)$ & $(10 \%)$ & $(15 \%)$ & $(100 \%)$ \\
\hline Withholding tax & 294 & 120 & 140 & 554 \\
& $(53 \%)$ & $(22 \%)$ & $(25 \%)$ & $(100 \%)$ \\
\hline Source Survey res)
\end{tabular}

Source: Survey responses. 


\subsection{Gaps in the tax return forms}

While the different return forms were designed with macros to validate some information submitted, the level of verification is low. Some key variables such as TINs are not mandatory. Even in cases where some fields are mandatory, any information can be filled in and it is accepted.

\subsection{Weaknesses in the e-tax system and low level of systems integration}

The e-tax system suffers from a number of challenges. First, different system modules/databases within e-tax itself are not sufficiently integrated. As a result, the system is not able to validate some of the submitted information with information that is already available within different sub databases in e-tax. As discussed above, we have observed inconsistencies in information submitted in the same returns for separate periods, between different return types, and between the registration database and return data.

Second, the e-tax system is not integrated with other URA internal systems such as ASYCUDA World. Therefore, it is not able to validate information on customs data submitted through tax returns with that which is available in ASYCUDA World.

Third, URA systems generally are not integrated with any other external system. Some information such as on land and buildings could be verified with the property register at Kampala Capital City Authority or the land information system at the Ministry of Lands, Housing and Urban Development but these systems are not integrated despite all being systems of government agencies. Similarly, information on bank loans and interest declared in the income tax system could be verified if URA systems were integrated with bank systems.

\subsection{Weak return management processes}

There is currently no return verification and approval. Returns are automatically approved by the system. The implication is that whatever information is submitted by taxpayers is accepted as it is. The officers that used to verify and approve the returns were removed from the process following the challenge of low staff capacity to complete return verification and approval of all the submitted returns, as this used to result in delays in getting returns approved in the system.

\section{Conclusion and way forward}

The role of automation in improving tax administration efficiency in URA is generally acknowledged. Automation has helped to mitigate the various challenges of the manual system faced by both URA and taxpayers. However, there are a number of data quality gaps that may hinder accurate decision making. Specifically, we found: (a) a high proportion of incomplete returns and/or returns with inaccurate/wrong information, especially in regard to identification details, such as those of company directors in income tax returns, landlords and/or tenants in rental returns, and employees in PAYE returns; (b) a number of returns with inconsistent information; and (c) a sizeable number of returns amended, with some taxpayers amending the same return several times. Lastly, we found that the data gaps have persisted over the years and cut across different taxpayer segments - large, medium and small taxpayers, and government entities.

The data gaps are a result of: (a) people-related causes including taxpayers, tax agents, URA officers and management; (b) complexity of the return forms; (c) gaps in the return 
forms; (d) weaknesses in the e-tax system and low levels of system integrations; and (d) weak tax return management processes.

Going forward, URA will need to dedicate sufficient resources to ensuring that new tax return records are of sufficient quality. Specifically, we suggest that URA should:

- Upgrade the e-tax system so that different modules within e-tax are integrated to automatically verify some of the submitted information with that which is already available in the e-tax system. System integration between e-tax and other internal as well as external systems also needs to be implemented at least in the medium and long term.

- Pre-populate some of the information in the tax return. This may involve designing online return forms similar to the one for presumptive taxpayers. In this case, when a taxpayer specifies their TIN, information such as, for example, directors' details, the location of business premises, and opening stock (for income taxpayers), is automatically updated on the form.

- Deliberately penalise taxpayers for submitting wrong information. In cases where erroneous information is submitted, a penalty can be introduced. In customs, for instance, if an agent fraudulently declares on behalf of the taxpayer, he/she can be prosecuted and penalised (sections 147 and 148 of the East African Community Customs Management Act 2019 (EACCMA)).

- Teach taxpayers and tax agents how to file tax returns, and also teach them the implications of submitting wrong tax return information to URA. These trainings need to be continuous and well-structured and should specifically target those who are submitting wrong information. 


\section{References}

IMF (2019) Tax Administration Diagnostic Assessment Tool (TADAT): Performance Assessment Report for Uganda, Washington, DC: IMF

IMF (2016a) Tax Administration Diagnostic Assessment Tool (TADAT): Performance Assessment Report for Zambia, Washington, DC: IMF

IMF (2016b) Tax Administration Diagnostic Assessment Tool (TADAT): Performance Assessment Report for Tanzania, Washington, DC: IMF

IMF (2016c) Tax Administration Diagnostic Assessment Tool (TADAT): Performance Assessment Report for Kenya, Washington, DC: IMF

IMF (2015a) Current Challenges in Revenue Mobilisation: Improving Tax Compliance, Washington, DC: IMF

IMF (2015b) Tax Administration Diagnostic Assessment Tool (TADAT): Performance Assessment Report for Rwanda, Washington, DC: IMF

Jouste, M., Nalukwago, M. I., and Waiswa, R. (2012) Do Tax Administrative Interventions Targeted at Small Businesses Improve Tax Compliance and Revenue Collection? Evidence from Ugandan Administrative Tax Data, WIDER Working Paper 17/2021, UNU-WIDER

Mayega, J., Ssunna, R., Mubajje, M., Nalukwago, M. I. and Muwonge, L. (2019) How Clean is our Taxpayer Register? Data Management in the Uganda Revenue Authority, African Tax Administration Paper 12, Brighton: ICTD

MoFPED (2020) Annual Budget Performance Report FY 2019/20, Kampala: Ministry of Finance, Planning and Economic Development

Nathan Associates Inc (2018) Data Intelligence Assessment Report, Uganda Domestic Resource Mobilization for Development (DRM4D)

OECD (2007) Revenue Statistics in Asian Countries: Trends in Indonesia, Japan, Kazakhstan, Korea, Malaysia, the Philippines and Singapore

OECD (2006) Using Third Party Information Reports to Assist Taxpayers Meet their Return Filing Obligations - Country Experiences with the Use of Pre-Populated Personal Tax Returns

Saka, H., Waiswa, R. and Kangave, J. (2018) Taxing Government: The Case of the Uganda Revenue Authority's Public Sector Office

URA (2019) Domestic Tax Compliance Improvement Plan 2019/20 